UNIVERSIDADE DE SAO PAULO

INSTITUTO DE PSICOLOGIA

AIDA DUARTE BINZE

FAMÍLIA E DEFICIÊNCIA NO GRUPO ÉTNICO LINGUÍSTICO YAO DO NORTE DE MOÇAMBIQUE

São Paulo

2013 


\section{FAMÍLIA E DEFICIÊNCIA NO GRUPO ÉTNICO LINGUÍSTICO YAO DO} NORTE DE MOÇAMBIQUE

Dissertação apresentada ao Instituto de Psicologia da Universidade de São Paulo como requisito parcial para a obtenção do titulo de mestre em psicologia.

\section{Área de Concentração:}

Psicologia Escolar e do

Desenvolvimento Humano

Orientador:

Prof. Dr. Lineu Nório Kohatsu

São Paulo

2013 


\section{AUTORIZO A REPRODUÇÃO E DIVULGAÇÃO TOTAL OU PARCIAL DESTE TRABALHO, POR QUALQUER MEIO CONVENCIONAL OU ELETRÔNICO, PARA FINS DE ESTUDO E PESQUISA, DESDE QUE CITADA A FONTE.}

\section{Catalogação na publicação}

Biblioteca Dante Moreira Leite

Instituto de Psicologia da Universidade de São Paulo

Binze, Aida Duarte.

Família e deficiência no grupo etno-linguístico Yao do Norte de Moçambique / Aida Duarte Binze; orientador Lineu Nório Kohatsu. -São Paulo, 2013.

$85 \mathrm{f}$.

Dissertação (Mestrado - Programa de Pós-Graduação em Psicologia. Área de Concentração: Psicologia Escolar e do Desenvolvimento Humano) - Instituto de Psicologia da Universidade de São Paulo.

1. Família 2. Deficiência 3. Moçambique I. Título.

HQ10 


\section{FOLHA DE APROVAÇÃO}

Nome: BINZE, Aida Duarte

Titulo: Família e deficiência no grupo étnico linguístico Yao do norte de Moçambique.

Dissertação apresentada ao Instituto de Psicologia da Universidade de São Paulo como requisito parcial para a obtenção do titulo de mestre em psicologia.

Aprovado em:

\section{BANCA EXAMINADORA}

Prof .Dr: Instituição:

Julgamento: Assinatura:

$\operatorname{Prof}^{\mathrm{a}} \cdot \mathrm{Dr}^{\mathrm{a}}{ }^{\mathrm{a}}$ : Instituição:

Julgamento: Assinatura:

$\operatorname{Prof}^{\mathrm{a}} \cdot \operatorname{Dr}^{\mathrm{a}}$ : Instituição:

Julgamento: Assinatura: 


\section{DEDICATÓRIA}

Ao meu esposo Óscar Afonso Lapone, pelo apoio incondicional, pelo companheirismo e pela compreensão e paciência durante a minha prolongada ausência.

Aos meus Pais, Duarte Binze e Adelaide Mozene, pelos ensinamentos proporcionados é a eles eu devo tudo que sou hoje

Aos meus irmãos pelas vezes que os faltei nos momentos em que mais precisaram de mim, Santos Binze, Natalia Duarte, Fernando Duarte, Afonso Binze e Fernanda Binze. 


\section{AGRADECIMENTOS}

Ao meu Orientador Prof. Lineu Nório Kohatsu, pela orientação de forma sabia, paciente e incansável pois, sem ele esta caminhada seria cheio dificuldades.

A Professora, Marilene Proença uma mulher inspiradora que nunca me faltou nas vezes em que eu me senti fragilizada.

As Professoras, Denise Barros e Eloisa Dantino, pelas riquíssimas contribuições, que culminou com a finalização deste trabalho.

Ao Reitor da Universidade Pedagógica de Moçambique que tem investido incansavelmente na formação dos seus quadros.

A CNPq pela oportunidade de fazer a minha formação neste País.

Ao Ministério de Ciências e tecnologias de Moçambique, pelo investimento que tem empreendido na formação dos jovens Moçambicanos.

Aos meus Professores, Claire Skkell, Maria Luiza, José Leon Crochík, a Beatriz Paula de Souza pelos ensinamentos transmitidos.

A minha sogra Marta, aos cunhadas Teresa Afonso, Laura Afonso, Inês Afonso, Teófila Afonso e Cacilda Afonso, Joaquim Caronga, Omar, pelo apoio que deram durante estes dois anos de aprendizado.

Aos meus Primos Ana Maria, Julio, Laura, Justina, Alice, Sérgio e todos aqueles que de certa forma contribuíram nesse processo de formação.

Aos meus sobrinhos Chana, Ayondela, Maninho, Jeny, Haraldina, Nilton pelo carinho.

A minha família do Brasil, Deborah Barbosa, Myrian, Matheus, Neyde, Moura, Ana Nhampule a estes vai um agradecimento especial, terem me colocado dentro da suas casas de forma incondicional mesmo sem me conhecer.

Aos meus amigos me faltam palavras para dizer o quanto vocês são importantes para mim, a Mary vai um abraço muito especial pela entrega e dedicação em todos os momentos que eu precisei, a Tânia, Viviane, Alan, Fernanda, Josilana , Bruno , Hilusca, Cristiane, Laura, Papucides, Chicamisse, Emanuel, Anibal, Vicente, Tome, Salvador, Joaquim, Fernando, Lucia Omar, Binta, Albertina, Lusitaneo, Felícia, Lucia, Djon, Carlos, Ana Maria, Tique, Flávio. 
Aos meus chefes e colegas de trabalho da Universidade Pedagógica de Moçambique delegação do Niassa .

Aos meus alunos que sempre estiveram do meu lado.

Aos funcionários do Departamento de Psicologia de Aprendizagem e da Personalidade que pacientemente souberam me orientar nos momentos em que tive dificuldades, $o$ meu muito obrigado vai ao Ary e a Olivia.

A Dalva do CCINTE do Instituto de Psicologia

As assistentes sociais, Eliane, Carla dentre outras.

Aos funcionários da Biblioteca do Instituto de Psicologia, que sempre se mostraram disponíveis para esclarecer qualquer dúvida.

Enfim a todos aqueles que não pude mencionar aqui, mas que de forma direta ou indiretamente contribuíram na minha formação. 


\section{RESUMO}

O objetivo da pesquisa foi investigar a relação de uma família do grupo étnicolinguístico Yao com um filho deficiente. Para a coleta de dados foi realizado um trabalho de campo no Distrito de Sanga, província de Lichinga, Moçambique. Foram feitas cinco visitas a uma família, com duração aproximada de duas horas diárias, sendo realizadas observações da rotina e conversas com a família, principalmente com a mãe. A família é constituída por dez pessoas, sendo a mãe, seis filhos, entre eles um jovem de 16 anos com deficiência intelectual, e duas avós, uma materna e a outra paterna e um neto. A família apresenta um nível sócio-econômico baixo, não recebem nenhum auxílio financeiro governamental e o sustento vem basicamente da atividade agrícola de subsistência. Todos os membros da família são analfabetos e só falam a língua Yao, sendo necessário o auxílio de uma intérprete para a coleta de dados. Além das observações e conversas com a família, foram realizadas também entrevistas com o líder da comunidade, o curandeiro, a parteira e os agentes sociais. A partir da sistematização dos dados foram propostos os eixos de análise, a saber: dinâmica familiar e participação do jovem Bernardo na rotina da família e da comunidade; explicação da mãe sobre a condição do filho e aspectos referentes à relação entre a família e a pesquisadora. Sobre a dinâmica familiar pode se notar relações afetuosas entre todos membros da família e inclusive no tratamento em relação à Bernardo. Todavia, segundo relato da mãe, não confirmado pela observação, Bernardo fica acorrentado porque invade as casas da vizinhança e pega seus pertences. As interações entre Bernardo e os membros da família são esporádicos, pois o jovem não se comunica verbalmente e fica praticamente o tempo todo isolado, de pé, parado em um canto do terreno da casa. Não passou pelos rituais de iniciação comuns na cultura Yao. A condição de Bernardo, foi explicada pelo curandeiro à mãe, pois a mesma não obteve esclarecimento satisfatório dos médicos. Segundo o curandeiro, a doença de Bernardo é causada pela presença do espírito do irmão gêmeo falecido no momento do parto. A partir do confronto dos dados coletados com outros estudos pode-se notar que várias manifestações decorrentes da presença da deficiência apontadas pela literatura não foram observadas na relação entre a família o jovem Bernardo. Todavia, o pouco tempo de permanência no campo não permite afirmações mais seguras, assim como se torna difícil avaliar o quanto este jovem está incluído ou não na família e na comunidade sem conhecer mais profundamente as referencias culturais. Nesse sentido, esta pesquisa se encerra apontando a necessidade de se realizar mais estudos para se conhecer os significados da deficiência nos diversos grupos étnico-linguísticos de Moçambique e avaliar mais precisamente as condições necessárias para se promover uma melhor qualidade de vida das pessoas com deficiência.

Palavras-chave: Deficiência, família, Yao. 


\begin{abstract}
The aim of this work was to investigate the relationship of an ethnic-linguistic Yao family with a disabled adolescent. For data collection a fieldwork in Sanga District, province of Lichinga, Mozambique was done. There were five visits to a family, which last about two hours a day, the visits held routine observations and conversations with the family, especially with the mother. The family consists of ten members, including the mother, six children, a 16 year old with intellectual disabilities, and two grandmothers (one maternal and one paternal). The family has a low socioeconomic status, receive no financial aid from the government. Their support comes primarily from subsistence agricultural activity. All family members are illiterate and only speak the Yao language, requiring the assistance of an interpreter for the data collection. Besides observations and conversations with the family, interviews with community leader, healer, midwife and social agents were also carried out. After data systematization, axes of analysis were set: family dynamics and participation of the young Bernardo in the family routine and in the community; mother's description about the condition of child and aspects concerning the relationship between the family and the researcher. On family dynamics, it can be noted an affectionate relationships between all family members including Bernardo. However, according to the mothers' reports, unconfirmed by observation, Bernardo is chained because he invades homes in the neighborhood and takes their belongings. Interactions between Bernardo and family members are sporadic because he cannot communicate verbally, and is almost constantly isolated, in his feet, standing in a corner of the house; he has not passed the initiation rites of culture Yao. The condition of Bernardo, was explained by the healer to the mother, because she did not obtain satisfactory clarification from doctors. According to the healer, Bernardo's illness is caused by the presence of the spirit of his twin brother died at birth. Comparing data collected in this work with other studies it may be noted that various manifestations about the presence of disability by the literature were not observed in the relationship between young Bernardo and his family. However, the short time spent in the field does not allow definite statement, as it is difficult to assess how much this young man is included or not in the family and in the community without a deeper understanding of the cultural references. In this sense, this research concludes pointing out the need to perform more studies in order to know the meanings of disability in various ethno-linguistic groups from Mozambique and evaluate more precisely the necessary conditions to promote a better quality of life for people with disabilities.
\end{abstract}

key words: Disability, Family, Yao ethnic. 
GLOSSÁRIO: de palavras em línguas Moçambicanas

EKWI: Vida

KULASSIYA: Cerimonia

KUNKOPOSYA MWANACE MLULI: Retirar a criança de dentro de casa

KUNKUNDA MWANACE MESI: Colocar água nas costas da criança

LINGANO: Doença que faz com que as crianças nasçam mortos

LOBOLO: Casamento tradicional

LOKWESO OU MWELA: Bilharziose ou elefantiase

NDAKA: Astenia profunda

OLHOMEY EKUME: Esterilidade

PALHOTA: Tipo de casa predominante na zona rural

TCHUMA: Riqueza

UKUMA: Bebidas

UNYAGO: Ritos de iniciação

WALIMU: Professor 


\section{SUMÁRIO}

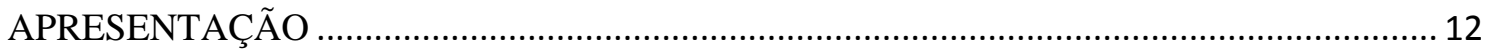

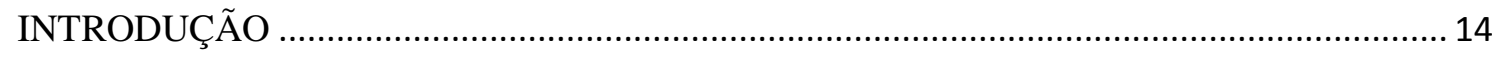

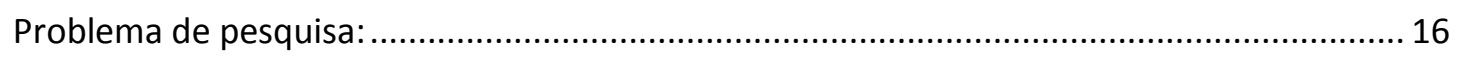

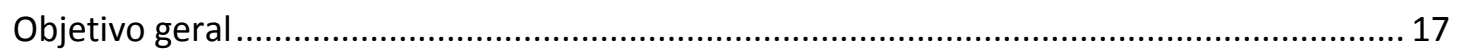

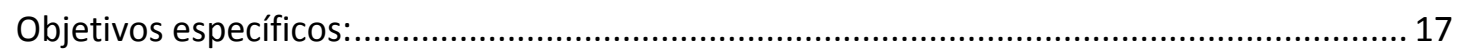

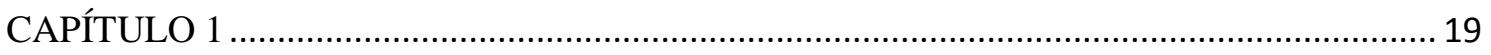

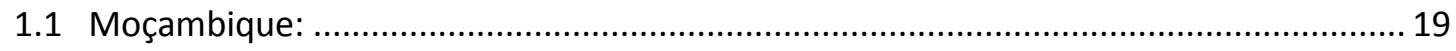

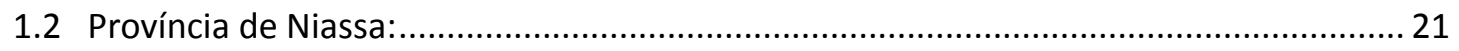

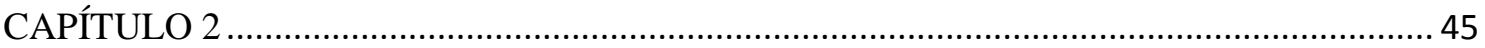

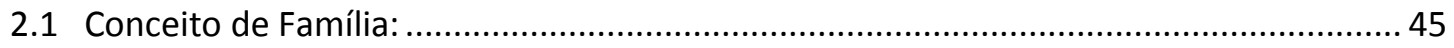

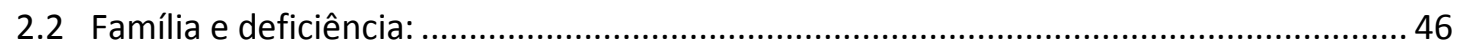

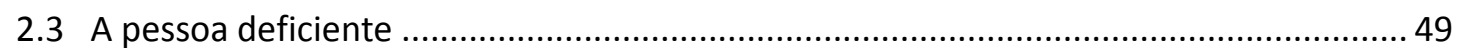

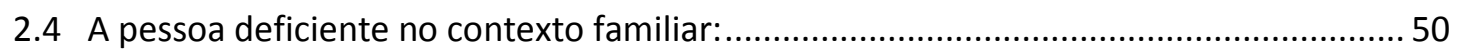

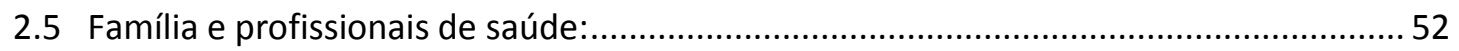

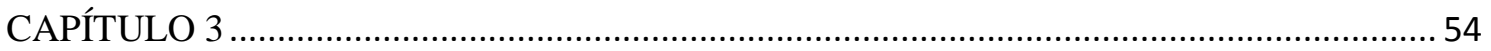

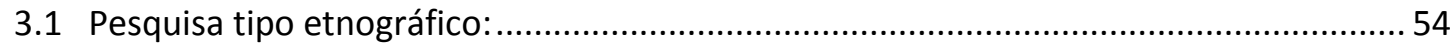

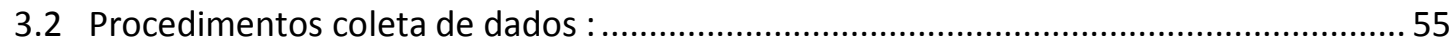

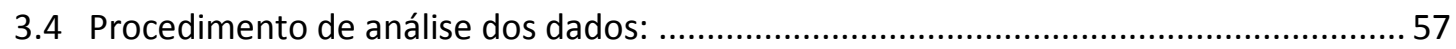

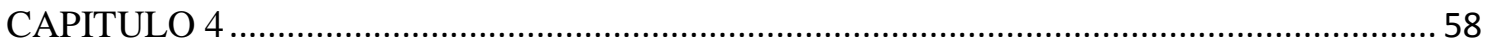

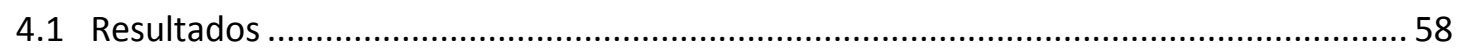

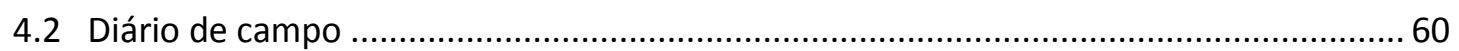

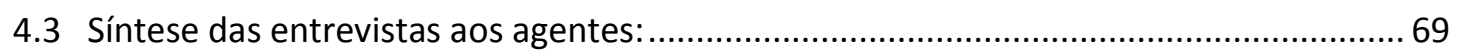

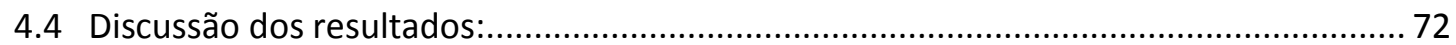

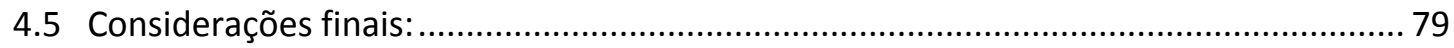

ANEXO 


\section{APRESENTAÇÃO}

Sou cidadã moçambicana, nascida na cidade de Nampula, província com mesmo nome Nampula, residindo atualmente na província de Niassa cidade de Lichinga.

Atuo como professora há 14 anos, em diferentes níveis de ensino, a destacar: ensino primário, que no Brasil corresponde ao ensino fundamental, nível médio e desde 2009 sou professora da Universidade Pedagógica de Moçambique.

Tinha como projeto de vida abrir uma creche. E assistindo aos programas diretamente do Brasil, especialmente trabalhos naquela altura da Sociedade Pestalozzi, decidi ampliar este projeto para crianças com necessidades especiais. Tendo consciência de que o que eu tinha de conhecimento na área de educação especial, assim como em educação infantil, eram insuficientes para seguir em frente com o projeto, acabei me inscrevendo num curso a distância on line disponibilizados pelo portal de educação denominado "Educação na infância", a partir do Brasil.

Portanto, eu sempre vi o Brasil como o lugar onde eu podia buscar mais conhecimentos, uma vez que sempre acompanhei trabalhos realizados neste País na área de apoio a pessoas com deficiência. Um dos trabalhos que mais me chamou atenção naquela época era o da Sociedade Pestalozzi, como afirmei anteriormente.

Quando eu fui desenhando este projeto, várias pessoas em Moçambique desencorajaram-me a seguir em frente, com alegação que esta questão não fazia parte da prioridade do Governo Moçambicano, incentivando-me desta forma a trabalhar com temas como HIV-SIDA, visto que eu já tinha contacto com a questão e tinham várias ONGs financiando projetos que falassem sobre esta temática.

Nessa altura surgiu uma oportunidade de cá vir, a partir de um concurso que anualmente é lançado em Moçambique pelo Ministério de Ciências e Tecnologias numa parceria com o CNPq-Brasil, que oferece bolsas para pós-graduação. Prestei o concurso e fui selecionada. 
Eu nunca tinha tido contacto com crianças com necessidades especiais, sendo a única experiência que mais me marcou, foi em conversa com uma pessoa conhecida nessa época. Eu sabia que ela tinha três filhos, e que um deles tinha Síndrome de Down e que era uma criança que dificilmente aparecia em público como os outros dois irmãos; poucas pessoas sabiam da existência desta.

Durante a conversa ela apenas citava o nome de dois dos filhos, foi quando eu a perguntei afinal quantos filhos ela tinha. Ela respondeu dois, ao invés de três, onde o terceiro não mencionado tinha Síndrome de Down.

Foi neste contexto que surge o presente projecto na tentativa de compreender as relações estabelecidas no seio da família e da comunidade frente a uma pessoa com deficiência, considerando ainda que a maior parte da sociedade moçambicana é tradicional com práticas culturais também diversificadas de região para região, embora algumas sejam pouco parecidas uma das outras. 


\section{INTRODUÇÃO}

Num primeiro momento, tinha como perspectiva estudar o que estaria por trás do não aparecimento de crianças com Síndrome de Down em Moçambique. Diante das dificuldades para encontrar famílias que tenham crianças ou mesmo adultos com esta deficiência, optei em ampliar a temática para deficiência no geral.

O estudo da temática da deficiência é bastante importante, visto que pouco se fala desta questão em Moçambique e existem poucos trabalhos abordando a questão da deficiência relacionando-a aos aspectos culturais. Porém existem alguns trabalhos em Moçambique que falam da deficiência principalmente no que diz respeito à educação especial.

Um exemplo claro foi durante a minha busca por trabalhos que abordassem o assunto em Moçambique, não encontrei nenhum trazendo este fator cultural, mas sim, de trabalhos focados na educação especial no geral, como é o caso da Dissertação de Mestrado do moçambicano Luís Alfredo Chambal, defendida na PUC-São Paulo com o tema "Escolarização dos alunos com deficiência em Moçambique: Um Estudo Sobre a Implementação e os Resultados das Políticas da Inclusão Escolar”(1999-2006).

Existem alguns trabalhos produzidos no Brasil sobre a temática. Porém, poucos dos que eu tive acesso apresentavam o aspecto cultural como um provável fator que faz com essas pessoas sejam excluídas do meio social, algo que pretendo trazer neste trabalho.

Cultura, no caso, pode ser entendida como sendo a totalidade do modo de vida de um povo ou comunidade. Segundo Boletim da República de Moçambique ${ }^{1}$, Cultura define-se como: sendo um conjunto complexo de maneiras de ser, estar, comportar-se e relacionar-se desde o nascimento até a morte passando pelos rituais que marcaram os principais momentos do processo de integração social e de socialização.

\footnotetext{
${ }^{1} 1^{\text {a }}$ serie. Nr. 23, supl, de 10 de junho de 1997,
} 
Cultura compreende: os aspectos criativos; as artes visuais e cênicas; as matérias: vestuários, arquitetura e instrumentos de trabalho; os institucionais: as estruturas econômicas, sociais, políticas e militares, os filosóficos: ideias, crenças e valores $^{2}$.

Um dos objetivos, como estratégias de implementação que o documento apresenta é o de: promover o respeito, a valorização e aceitação do patrimônio cultural e artístico de cada comunidade. E nestes aspetos apontados em que pretendemos nos basear neste trabalho, visto que, o conceito de cultura engloba vários outros aspetos que aqui não foram mencionados.

Portanto uma vez que o conceito de cultura é bastante amplo e complexo, não se pode resumir em alguns aspectos apenas mas sim numa totalidade de fatores em que a própria natureza proporciona.

Por exemplo o curandeiro nestas comunidades tem um papel muito importante, uma vez que, ele é uma pessoa a qual a comunidade acredita nos seus feitos, na sua palavra. Falo aqui dos curandeiros, mas existem outras figuras e aspetos que são muito valorizados por estas comunidades. Temos a figura do líder tradicional (régulo), os rituais de passagens vulgo (nyago). De alguma forma essas práticas servem para unir as pessoas, nessas regiões, criando assim uma estabilidade e harmonia social.

No âmbito legal em Moçambique existe um movimento no sentido, criar uma estabilidade às pessoas com deficiência ainda que seja a passos lentos. A Constituição da República de Moçambique, 2004, apresenta alguns artigos que tratam de assuntos relacionados às pessoas com deficiência. São três artigos específicos que tratam da deficiência. O Artigo 37 refere-se à garantia dos direitos e deveres iguais para todos; o Artigo 121 diz respeito às crianças com deficiência, não descriminação e maus tratos; e o Artigo 125 trata do acesso à educação e a aprendizagem em línguas de sinais.

Nota-se, todavia, que em alguns artigos dispostos pela Constituição de Moçambique, por exemplo, o artigo 228 que trata do acesso à educação nas escolas regulares, não contempla necessidades específicas que algumas pessoas com deficiência

\footnotetext{
${ }^{2}$ resolução $\mathrm{nr} 12 / 97$ de 10 de junho de 1997).
} 
podem apresentar. Estas questões são abordadas à parte, somente em artigos relacionados às pessoas com deficiência, como por exemplo, o artigo 125, referente à aprendizagem em línguas de sinais.

Com as discussões trazidas por vários autores na área da deficiência com Lígia Amaral, por exemplo, dá para se dizer que ainda tem muito a se fazer e pesquisar questões ligadas a deficiência, porque o que existe ainda é insuficiente para esclarecer e guiar atitudes para aceitação da deficiência.

Entendo também que é importante oferecer espaço para que as pessoas com deficiência possam se manifestar, para que elas próprias possam denunciar as barreiras existentes e todos, conjuntamente, possam eliminá-las.

Vale apena frisar que em Moçambique existem várias etnias, cada uma delas com hábitos e costumes diferentes uma das outras, embora algumas práticas sejam parecidas. Por outro lado, a despeito da diversidade étnica e cultural, é preciso não esquecer que a lei é mesma para todos.

Uma pessoa normal ou sem deficiência em Moçambique e principalmente em Sanga, região que foi feita a pesquisa, participa de todas as atividades do cotidiano. Vão às machambas ${ }^{3}$, aos rituais de passagem, vão ao rio, vão à caça, trabalham, estudam etc. Restava-se saber como era no caso de pessoas com deficiência.

Como referido anteriormente, em Moçambique existem várias etnias - mais de 24. Sanga, situado na Província de Niassa, existem três: Macuas, Nyanjas e Yao. O grupo escolhido para fazer parte da pesquisa são os Yaos, pela sua história que julgo interessante como evidenciarei, mais em diante.

Porém em momento algum quero desvalorizar a história das outras etnias, mas o contacto e convivência com este grupo, uma vez que atualmente estou residindo em Niassa, provocou em mim mais interesse em entender melhor a sua história, a sua cultura e tudo que faz parte deste grupo e principalmente questões ligadas a deficiência.

\section{Problema de pesquisa:}

\footnotetext{
${ }^{3}$ No Brasil, diz-se roca
} 
A partir das considerações feitas anteriormente, foram elaboradas as seguintes questões:

- O que tem acontecido dentro da família, quando existe uma criança com deficiência?

- Qual é a relação que a comunidade Yao mantém com uma família que tenha um filho com deficiência?

- Será que as crianças com deficiência participam da vida social Yao tal como as demais crianças? Se existem restrições, como elas são justificadas pela família e pelos membros da comunidade, considerando suas tradições e crenças?

- Qual é a relação que os agentes de saúde da Ação social mantêm com as famílias que tenham um filho com deficiência?

A inserção dos agentes de saúde na pesquisa deve-se pelo fato, de terem uma visão geral dos casos de deficiência que saem dos seus serviços ou que por eles são assistidos.

Dos agentes de saúde procura-se entender sobre o ponto de situação das pessoas com deficiência no que diz respeito aos dados e qual é o impacto dessas famílias quando se está diante de um filho com deficiência.

Dos agentes da ação social procura-se entender os casos que eles têm recebidos com frequência aos seus serviços, em que situação essas pessoas chegam a eles e quais são os serviços oferecidos.

\section{Objetivos da pesquisa:}

\section{Objetivo geral:}

Investigar a relação da família com um filho deficiente, no grupo étnicolinguístico Yao, a partir da história cultural, hábitos, costumes do povo Yao e a relação estabelecida pela comunidade e essa família.

\section{Objetivos específicos:}


- Investigar as ações do universo e do cotidiano, que evolvem esta família e principalmente esta criança.

- Investigar os principais fatores que influenciam as várias ações que envolvam esta criança junto da família.

- Entender a relação da cultura Yao com a criança deficiente.

Para concretização dos objetivos, foi realizada observação onde primeiramente procurou-se entender a história, a vida hábitos e costumes do povo Yao, o cotidiano de uma família com tenha um filho deficiente e sua relação com a comunidade. Foram realizadas também entrevistas com o líder tradicional, agente da ação social, da saúde e curandeiro.

O trabalho foi realizado em Moçambique, na Província de Lichinga, e no distrito de Sanga. Contou com a participação de uma família que tem um filho com deficiência intelectual que reside neste distrito. A história do rapaz é que ele estaria possuído pelo espírito do irmão gêmeo falecido.

Nesse sentido, a pesquisa apresenta a seguinte estrutura: no Capítulo 1 apresentarei algumas informações sobre Moçambique, sua localização, sua história, a divisão administrativa das províncias e população; a província de Niassa, o Distrito de Sanga e o povo Yao e a sua história, hábitos e custumes mitos e seus tabus. No Capítulo 2 discutirei a relação família-deficiência: concepção de família, o impacto provocado pela presença da deficiência e as formas de superação. No Capítulo 3 abordarei o método que foi adotado nesta pesquisa. No capitulo 4 abordarei os resultados e sua respectiva discussão . Por fim apresento as consideraçãoes finais. 


\section{CAPÍTULO 1}

O presente capítulo vai abordar um pouco de Moçambique, da Província de Niassa, o Distrito de Mavago e o povo Yao: sua história, hábitos e costumes, mitos e seus tabus.

\subsection{Moçambique:}

Moçambique situa-se na faixa sul oriental do continente africano. Ao Norte limitado com a Tanzânia; à Oeste com Malawi, Zambia, Zimbawe e Suazilândia; ao Sul com África do Sul e a Este é banhado pelo Oceano Índico. A superfície territorial é de $799.380 \mathrm{~km} 2$ e tem 11 províncias assim divididas.

Ao Norte - Niassa, Cabo Delgado e Nampula; ao Centro - Zambézia, Tete, Manica e Sofala; ao Sul - Inhambane, Gaza, Maputo e Maputo Cidade. De acordo com o Censo da População e Habitação de 2007, Moçambique possui cerca de 20,5 milhões de habitantes e cerca de $70 \%$ da população vive em zonas rurais. Moçambique tem mais de 24 etnias, e por isso rico culturalmente. Eis algumas delas: Macua, Maconde, Yao, Cena Nhungue, Ndau, Changana, Maxope dentre outras, com culturas, hábitos totalmente diferentes uma das outras. Vide a figura 1.

"As línguas nacionais constituem um importante patrimônio por serem o principal repositório e veículo das tradições nacionais, instrumentos de comunicação da maioria dos Moçambicanos e elemento fundamental para o envolvimento dos cidadãos na vida social, econômica e política”.( Resolução nr. 12/97 de 10 de junho)

\section{a) Religião:}

Crenças tradicionais (50\%), cristianismo (39\%), islamismo (10,2\%), outras $(0,2 \%)$, sem religião e ateísmo $(0,6 \%)$ (Fonte: http://www.suapesquisa.com/paises/mocambique/: Acesso, 21 Set.2012). 


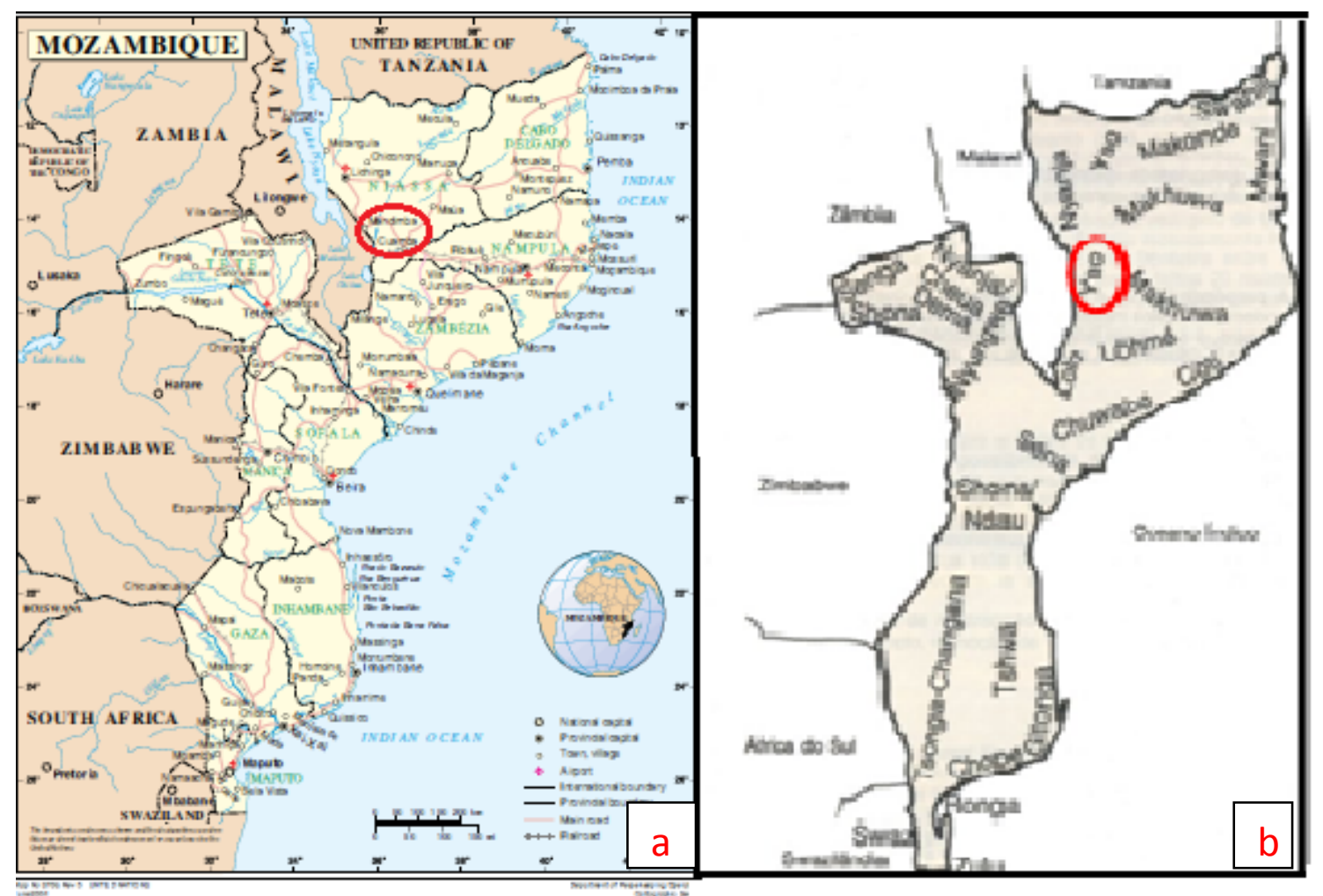

Fig. 1 : a) Mapa de Moçambique; b) Distribuição geográfica de algumas línguas

Figura 1 - a)Fonte: http://www.un.org/Depts/Cartographic/map/profile/mozambiq.pdf, Acesso: dia 15 de Março de 2013

Figura 1-b) Fonte: http://paginaglobal.blogspot.com.br/2012/07/mocambique-o-paisque-esta-conquistar-o.html. 2012

\section{b) População/ breve história do povo Moçambicano:}

Cerca de 20,9 milhões de habitantes, ocupando uma extensão territorial de aproximadamente $799.380 \mathrm{Km}^{2}$, Moçambique é a mais populosa das antigas colônias portuguesas da África. A agricultura é à base da economia do país.

Normalmente, o português não é a língua materna. É aprendida, na maioria das vezes, em sua forma oral, em casa e na modalidade escrita, na escola, carrega a estatura de língua padrão unificadora. 


\subsection{Província de Niassa:}

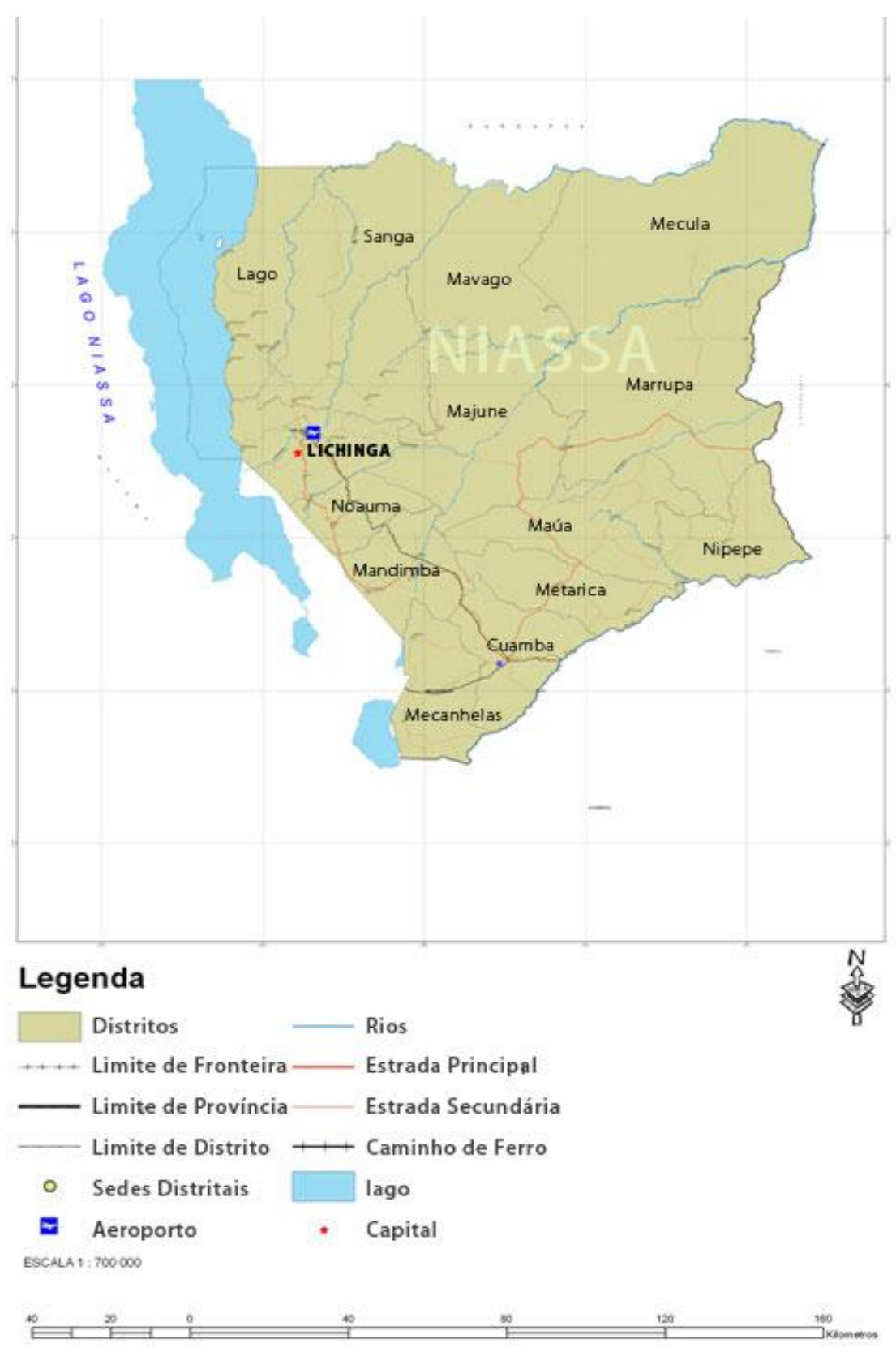

Figura 2 - Mapa da província de Niassa

Fonte: www.todosmapas.com/mapa-de-lichinga-em mz-cddb, acesso: 15 de Marco de 2013, 14:30horas.

Niassa é uma província no nordeste de Moçambique. A sua capital é Lichinga e está situada a cerca de 2800 km de Maputo. Em 2007, Niassa era a maior província do 


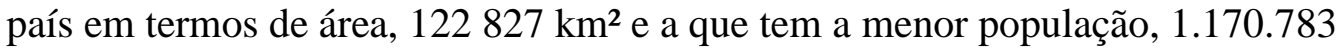
residentes, o que naturalmente implica a menor densidade populacional entre as províncias moçambicanas, com apenas 9,5 habitantes por $\mathrm{km}^{2}$.

Niassa está dividida em 16 distritos e possui 4 municípios: Lichinga, Cuamba, Marrupa e Metangula. A província do Niassa faz fronteira a norte com a Tanzânia, a sul com as províncias de Nampula e Zambézia, com a província de Cabo Delgado a este e a oeste com o Malawi com o qual também divide o Lago Niassa que é um dos grandes lagos africanos.

É montanhosa e foi muito afetada pela luta Armada de Libertação Nacional. Apesar de ter muitas riquezas naturais uma das quais, a costa mais alcantilada do lago Niassa onde neste momento se está a desenvolver o turísmo e excelentes solo e clima, esta região nunca se desenvolveu como as regiões costeiras. No período pré-colonial, Niassa era uma importante fonte de marfim no comércio regional e mesmo internacional através do Oceano Indico. (Fonte: <http://www.niassa.gov.mz/> Acesso em: 21 set. 2012).

Lichinga é uma cidade com características econômicas eminentemente agrícolas, possui pequenas indústrias de processamento primário de produtos agrícolas. A rede de infraestruturas é ainda incipiente. E tem como principais atividades econômicas: a agricultura (cultivo de milho, feijão, batata, criação de animas e hortícolas). Há cinco instituições Bancárias, prática de turismos de infraestruturas, existindo dezoito (18) estabelecimentos hoteleiros.

A população embora dentro de grande diversidade étnico-culturais, com predomínio de ayos, macuas, Nyanjas e outros grupos e professam as religiões muçulmana, católica e anglicana.

\section{a) Distrito de Sanga}

O Distrito de Sanga fica situado na parte Norte da Província, de Niassa, a $60 \mathrm{~km}$ da capital Provincial, Lichinga, confinando a Norte com a República de Tanzânia, a Sul com os Distritos de Lichinga, a Leste com os distritos de Muembe e Mavago e a Oeste com distrito de Lago. Com uma superfície, de 13.439 km2, e uma população de 44.225, segundo o censo da população e habitação de 1997. Os solos desta área destacam-se 
pela elevada fertilidade e grande potencial agrícola constituindo, assim, a zona agroecológica 10.

Em termos de infraestruturas, o distrito conta com transporte rodoviário como única via de comunicação com os pontos dentro e fora do país. A $\mathrm{EN}^{4} 537$ que liga Unango a Lichinga está transitável em toda sua extensão de $64 \mathrm{~km}$. O acesso à água potável continua ser uma necessidade não satisfeita. Na época seca alguns furos e poços secam, obrigando a população a recorrer às fontes de água não melhoradas como rios, lagos e charcos. De acordo com os dados do Censo de 1997, o fornecimento de energia ás famílias neste distrito é quase nulo.

O distrito possui 37 escolas (das quais, 33 do ensino primário, nível 1), e está servido por 10 unidades sanitárias, que possibilitam o acesso progressivo da população aos serviços do Sistema Nacional de Saúde. Porém estes serviços não são suficientes para atender a demanda como mostra o seguinte índice de cobertura:

- Uma unidade sanitária por cada sete mil pessoas;

- Uma cama por 2.300 habitantes; e

- Um profissional técnico para cada 2.500 residentes no distrito.

A taxa de analfabetismo e de escolarização, no Distrito de Sanga é muito baixa. Cerca de $80 \%$ da população é analfabeta, predominantemente mulheres, constando que, somente $26 \%$ dos habitantes frequentam ou já frequentaram a escola, segundo os dados de 1997 do Instituto Nacional de Estatística.

Apesar dos esforços realizados, importa reter que o estado geral de conservação e manutenção das infraestruturas, não é suficiente, sendo de realçar a rede de bombas da água a necessitar de manutenção, bem como a rede de estradas e pontes que, na época das chuvas, tem problemas de vias de acesso.

A agricultura é a atividade dominante e envolve quase todos os agregados familiares. De um modo geral, a agricultura é praticada em pequenas explorações familiares em regime de consorciação de culturas com base em variedades locais. Não

\footnotetext{
${ }^{4}$ Estrada Nacional
} 
existe nenhuma instituição bancaria a operar no distrito, nem nenhum sistema formal de crédito em condições acessíveis aos operadores locais.

\section{- História e cultura da população de Sanga}

A população de Sanga é maioritariamente, de origem Yao ou Ajaus com regimes matrilineares, onde o poder assenta na família da mulher. O Yao é a língua mais falada, seguindo-se o Ngoni e Swahili, esta última devido à influência da Tanzânia. Uma vez que a língua mais falada é o Yao, 73\% da população do distrito com cinco ou mais anos de idade não sabem português, sendo o seu conhecimento preferencial nos homens dada a maior inserção na vida social e escolar como também no mercado de trabalho.

A religião predominante é a muçulmana, sendo praticada por cerca $90 \%$ da população. Uma minoria professa a religião Cristã. O poder predominante no distrito é do estado com certa representatividade das autoridades tradicionais. Os líderes tradicionais tratam principalmente dos aspectos tradicionais, tais como: cerimônias, ritos e conflitos sociais. Fonte:

(http://www.portaldogoverno.gov.mz/Informacao/distritos/niassa/Sanga.pdf Acesso em 17 de Marc, 2013)

Segundo Amide (2008), Niassa foi visto, desde muito tempo, como desconhecido Niassa, Esquecido Niassa, o Niassa abandonado, o Niassa Pobre e mais expressões, que não agradavam aos ouvidos de um natural do Niassa, diz ainda este autor.

Este Niassa já foi conhecido e mesmo a nível internacional pelo valentiado régulo Mataka. Felizmente o Niassa está a crescer em muitos sentidos, a nível econômico, cultural, já com vários intelectuais em todas as esferas do saber, isto fez com que, o desconhecido Niassa não exista, mas sim o conhecido Niassa e o orgulho. Niassa tem grandes recursos naturais e potêncialidades para poder ser hoje e sempre "grande Niassa".

\section{b) Etnias predominantes na província de Niassa}

No presente capítulo faço breves considerações sobre três grupos étnolinguísticos, mais representativos, da província do Niassa (norte de Moçambique), a 
saber: os Macua, os Nyanja e os Yao, com destaque para este último que é a etnia que pretendo trabalhar na minha pesquisa, com o propósito de fazer entender ao leitor como é a cultura desse povo que respeita bastante os seus valores socioculturais. A obra "O povo Yao (mtundu wayao)", de Manuel Gomes da Gama Amaral (1990) foi de extrema importância na elaboração deste capítulo.

\section{c) Religião no Niassa}

Segundo Wegher, Todos os Bantus, da África Meridional, Ocidental e Oriental, que, como e sabido pelos etnólogos teve a mesma origem, conserva também os mesmos valores religiosos, naturalmente com algumas diferenças entre eles, mantendo-se iguais quanto à substância da religiosidade.

É geral a opinião de serem os Bantus um povo religioso, que acredita num só Deus: deus supremo. Admite-se também que a religião dos Bantus, como nota dominante, volta-se para os antepassados, isto é os espíritos dos antepassados é que são, na pratica o centro de todo culto.

Com a entrada da religião muçulmana na tribo Yao, ao tempo do Mataka, não foram somente os homens a sujeitar-se a influência, às vezes violenta, do Islamismo, mas as mulheres também chegaram a ter nisto um papel importante.

\section{d) Os Macua:}

O povo Macua vive atualmente numa grande área ao norte de Moçambique, com cerca $300.000 \mathrm{~km} 2$, que abrange parte das províncias de Cabo Delgado, Nampula e Zambézia. O território é conhecido historicamente pelo nome de "macuana", é delimitado, a norte, pelo rio Rovuma; a leste pelo oceano índico; a sul pelo Licungo, nas proximidades do rio Zambeze e a este pelo rio Lugenda.

Os Macuas representam o grupo étnico-linguístico mais numeroso de Moçambique, tomando várias designações conforme a região que povoam: Lomúes na Maganja da Costa; Pebane, Ile, Gurue, Namaroi e Amaramba, Achirimas em Ribaue e 
Alto Ligonha; Macas em Mogincual e Moma; Methos ou Amethos ou Medos, em Montepuez; e Mecufi, Chacas; no Erati e Mecufi, Muages; e Macuas propriamente ditos em Nampula (Makwana $)^{5}$.

Os Yao designam, genericamente, os Macuas por Lolos ou Alolo e ainda, por Ngulo ou Ângulo. Esta designação Alolo é tomada, também, por subgrupos macuas que habitam parte dos conselhos de Milange e de Mocuba e das circunscrições administrativas de Murrumbala e de Mopeia, na Zambezia.

A habitação tradicional dos Macuas é circular com cobertura cônica, mas na região a que nos estamos a referir, por influência Yao, já evoluiu para quadrada ou retangular com cobertura de quatro águas ${ }^{6}$ como os Yao, mantém de forma circular a cozinha e a retrete, bem como os celeiros.

A família Macua é baseada no direito matriarcal, sendo o regime familiar matrilinear e uxorilocal ${ }^{7}$ que consiste em, após o matrimônio, os cônjuges vão morar na casa da mulher, ou na mesma povoação.

Tal como entre os Yao, a sucessão e a herança diferem-se por via transversal uterina, isto é, a viúva é herdada pelo sobrinho, filho da irmã do defunto, isto é, se o marido morre, esta viúva automaticamente terá que se casar com o sobrinho do falecido ou seja esta viúva passa a ser esposa do filho da cunhada. Os tios maternos exercem grande autoridade ao agregado familiar. Praticam a circuncisão, que abre as cerimônias da iniciação masculina, designadas por Unwago. As cerimônias da iniciação feminina chamam Emwali ${ }^{8}$.

O povo Macua é formado por vários grupos em que os hábitos e as práticas culturais são diversificados de região para região sendo os mais importantes:

- Grupo Macua do interior (províncias de Nampula e Niassa).

- Grupo Macua-meto (províncias de Cabo Delgado e Niassa).

\footnotetext{
${ }^{5}$ É forma de se referir aos Macuas.

${ }^{6}$ Refere-se a um tipo de casa quadrada, em que a cobertura tem quatro divisões, e normalmente o material usado é caniço.

${ }^{7}$ Significa que o homem é que abandona sua terra e sua família para se juntar a sua esposa.

${ }^{8}$ Mulher iniciada
} 
- Grupo Macua-lomwe (províncias da Zambézia e Niassa).

Há vários grupos menores e subdivisões dos anteriores.

O nascimento de uma criança é um dos acontecimentos mais importantes da sociedade macua. A criança é desejada e esperada pelos pais, pelos responsáveis e membros da comunidade, porque todos amam a vida e desejam que esta continue. "Quando isto não acontece é motivo de tristeza". (AMIDE, 2008, p. 79).

Nos ritos de iniciação ensina-se que no mundo há tanta coisa que pode causar sofrimento: o trabalho, a doença, a pobreza, as calamidades naturais e outras vicissitudes.

Cada vez que nasce uma criança este ideal realiza-se concretamente. Outro filho significa, para a família e para a comunidade, a esperança concreta de que a vida não acaba, é sinal de que os antepassados continuam a ser intermediários entre a fonte da vida e a sociedade.

"Por isso, o nascimento de uma criança é motivo de: festa para toda a comunidade, dia de alegria para todos $[\ldots]$ os antepassados são os nossos ancestrais por meio dos quais, recebemos a vida e nos deixaram a herança da nossa tradição cultural. Os antepassados já morreram, “[...] estão agora em forma de espíritos que nos intercedem junto do criador da vida”. (AMIDE, 2008 p.80).

Quando nasce uma criança, todos sentem bem o valor supremo do povo, a vida (Ekmi), se torna mais forte, renova-se e desenvolve-se visivelmente a caminho da plenitude. A esterilidade (Othomeya Ekume) é algo sempre considerado, na sociedade Macua, como uma desgraça, um castigo ou maldição, consequência direta da transgressão de alguma lei, de um mau comportamento, ou ação de alguém que nos deseja mal.

O povo despreza o homem e a mulher estéreis porque suspendem a vida; sendo estéreis, opõem-se de fato a transmissão da vida. Com homens e mulheres assim quebra-se a ligação que nos une aos medianeiros da vida, interrompendo-se a corrente 
vital. Por isso, o povo mantém uma atitude de desdém para os estéreis e os que não casam.

\section{e) Os Nyanja:}

Os wanyanja, ou, simplesmente, nyanjas habitam uma estreita faixa do território, na margem oriental do lago Niassa. Sua vizinhança com os Yao tem determinado certa fusão entre as populações dos dois povos.

A origem porque é conhecido este povo, é relativamente recente e está bem presente, na sua tradição. Os nativos usavam a palavra "Nyasa”, para designarem o grande lago. Do mesmo modo adotaram as palavras wanyanja e wayasa (respectivamente em língua Chi-chewa e Yao, que apenas querem dizer, os de borda de água), ou, simplesmente, Nyanja e Nyasa (que apenas referem a uma grande massa de água) para designarem as populações que se encontram a marginar o lago. Estas populações, que a si próprias, jamais tinham atribuído esse nome, passaram, daí por diante, a adotá-lo, com naturalidade.

Este povo segue a tradição, muito generalizada em povos da África Central, de fixarem a sua origem na metade norte do continente Africano. Neste caso específico precisamente no deserto do Sahara. A organização social e familiar dos Nyanja é idêntica a dos Yao, bem como idênticos são os seus usos e costumes, pelo que, nos limitaremos a registar alguns pontos de divergência.

As cerimônias da iniciação dos rapazes, que, entre os Yao, se seguem: a circuncisão que é uma das práticas culturais mais importantes e que se desenvolve durante um período bastante longo de segregação em lugar isolado.

$\mathrm{Na}$ iniciação das mulheres elas são confinadas numa palhota ${ }^{9}$ distante da sua casa e instruídas na prática sexual. As cerimônias rituais não têm o significado nem obedecem às formalidades complicadas praticadas entre os Yao. $\mathrm{O}$ regime familiar é matrilinear e uxorilocal t tradicionalmente, no que segue a regra em uso dos povos da áfrica Central, estando, porém, a notar-se um acentuado movimento de transição para o regime patrilinear e virilocal.

\footnotetext{
${ }^{9}$ Refere-se a casas de material tradicional( barro, capim, bambus).
} 
Assim, a população Nyanja, fortemente cristalizada, que habita ao norte da Missão Anglicana de Messumba, já é preponderantemente patrilinear e virilocal entre a população, acentuadamente islamizada é mais em contacto com os Yao, que vive ao sul dessa Missão (que se situa a cerca de $10 \mathrm{~km}$ a norte de Metangula), ainda predomina o regime matrilinear e ulorilocal ${ }^{10}$. Entre toda a população Nyanja, porém, coexistem, ainda, os dois regimes familiares, podendo um homem, simultaneamente, realizar casamentos que imponham o pagamento de compensação e outros que não imponham o que não é comum.

A compensação - lobolo - pelo casamento virilocal, designada em Nyanja por uloola; o lobolo é também designado em Nyanja por Cuma (tchuma = riqueza, querendo referir a importância, que o noivo paga ao pai da noiva) que varia até um máximo de 1000 dólares e determina ao domicílio necessário da mulher, que passa a ser da povoação do marido, e ao do regime sucessório, quer na linhagem transmitida aos filhos, que é a do pai, quer no patrimônio conjugal.

\section{f) Os Yao}

Os Yao são um grupo étno-lingüístico de origem bantu que se fixou na região entre os rios Rovuma e Lugenda, no nordeste de Moçambique, hoje província do Niassa. De acordo com (Amaral, 1968) tem sido tradição generalizada entre os povos de origem bantu da África Meridional a filiação da sua origem em migrações antigas oriundas da metade norte da África. Também comum a muitos povos desta parte do continente, de filiarem a sua origem num acidente geográfico, normalmente numa montanha ou cadeia de montanhas. Os Yao fixam a sua origem no monte Yao, que fica a sul do Rovuma (Luuma) entre Nkuya e Likopolwe.

\section{- Vida individual e familiar e os seus mitos:}

"O mito [...] tem um caráter de verdadeira fé de um povo o qual aceita, docilmente, o que se deve pensar, os magnos problemas do mundo e da vida, do sobrenatural e dos seres humanos". (AMIDE 2008, p. 82).

Os mitos para esta comunidade servem para que as pessoas do mesmo grupo cultural compartilhem todas, da mesma maneira de pensar, dando uma coesão grupal.

\footnotetext{
${ }^{10}$ Quando é a mulher que é retirada da sua família para viver com a família do seu marido
} 
Os mitos justificam, fundamentam, reforçam e codificam as crenças e as práticas de uma sociedade. "Os mitos são uma espécie de dogmas para o mundo primitivo e civilizado". (Amide, 2008 p.86).

A primeira menstruação das mulheres Yao é motivo de cerimônia (unyago) ${ }^{11}$. Nesta cerimônia é lhes explicado com pormenor e teoricamente, na medida do saber das $A k a m u s i^{12}$, o que é a menstruação, bem como os cuidados a ter durante o período. Quando pela primeira vez aparece, a mãe ou a avó se encarrega de lhe explicar o que tem a fazer.

O período menstrual determina tabu tanto para a mulher como para seu marido, assim a mulher menstruada não deve: por sal na comida nem as panelas ao lume; inclinar-se sobre o fogo nem acendê-lo na presença do marido; fechar portas; olhar para o marido quando estiver deitada; usar fios de miçanga à cintura; deixar água num recipiente para ser bebida por um parente; por fermento na bebida (ukana); usar a esteira que lhe serviu durante o período menstrual quando voltar ao estado normal. Adicionalmente, o preceito islâmico lhe interdita a prática de relações sexuais durante o período menstrual.

Por outro lado o homem que tiver relações sexuais com a mulher menstruada passará a sofrer de dores de costas crônicas, ou contrárias Lukweso ou Mwela ${ }^{13} \mathrm{Não}$ se deve sentar onde ela se tenha sentado ou encostado até que o chão seja rebocado por ela depois de voltar ao estado normal.

Como a preparação da comida é encargo da mulher, e a interdição de prepará-la durante alguns dias por mês trazia inconvenientes, imaginaram uma forma de resolver o problema sem quebrarem o tabu. Assim, durante o período menstrual, a mulher na confecção dos alimentos limitava-se a preparar a panela e chamava uma criança para colocar ao fogo. A criança utilizada tem de ser muito jovem (quatro a cinco anos) para haver a certeza de que é virgem condição indispensável para o efeito -, além de que as crianças principalmente nesta faixa etária não estão sujeitas a tabu. Na altura de salgar a comida a mesma criança ou outra nas condições exigidas é chamada para que o faça.

\footnotetext{
${ }^{11}$ Refere-se as cerimônias de ritos de iniciação

${ }^{12}$ Refere-se as mestres de cerimônias e as mulheres responsáveis pelos ensinamentos no unyago

${ }^{13}$ Bilharziose ou elefantíase
} 
Tradicionalmente, acreditam os Yao que comida confeccionada por uma mulher em período menstrual, sem respeito dos cuidados acima descritos, provoca em quem a coma, dores de ventre ou de dentes, que dificilmente passarão. Após a primeira menstruação e cada uma das seguintes, encontra-se a mulher em condições de conceber, segundo a tradição Yao, pela seguinte forma: apenas uma das cópulas conduz à concepção, pelo que, para terem a certeza da paternidade dos filhos as mulheres deverão, em cada período livre, manter relações apenas com o marido, naturalmente para as que sejam casadas.

Para estas, porém, acreditam os Yao, que o nascituro se recusará a nascer se não for filho do marido, proporcionando um parto difícil à mulher, se, entretanto não confessar o adultério.

\section{- O nascimento de um filho (kupagwa mwanace):}

Durante a gravidez a mulher não toma precauções especiais em relação ao nascituro nem se processam quaisquer cerimônias ou ritos, salvo tratando-se de primeira gravidez. De um modo geral, a mulher grávida deverá abster-se de tomar refeições juntamente com mulheres que não mantenham uma vida sexual normal, pois se acredita que contato com mulheres desregradas pode de terminar um parto "infeliz" 14 .

Devem abster-se, também, de manter reações sexuais com o homem que não seja o próprio marido; interromper as relações sexuais durante um período variável de dois a três meses antes do parto; e não tomar refeições com pessoas desconhecidas, nem comer alimentos amargos.

A primeira gravidez é acompanhada, desde o início, pelos conselhos da avó e da mãe da mulher grávida, tal como é normal em qualquer sociedade. Realmente, a mulher só é considerada completamente iniciada, depois do nascimento do primeiro filho. É altura que ela ocupa de forma completa, a sua posição de preponderância na sociedade. Entre as mulheres que tiveram filhos e as que os não tiveram, há um pronunciado desnível social.

\footnotetext{
${ }^{14}$ Refere-se ao nascimento de crianças com qualquer tipo de deficiência, nati mortos ou morte de ambos, seja do bebé ou da própria mãe.
} 
Para além da maternidade (hospital), tradicionalmente o parto processa-se dentro de uma casa destinada, dentro da povoação e que não é, geralmente a casa da parturiente, mas sim uma casa da avó ou da mãe. Assistem ao parto as mulheres que já tenham sido mães, tanto da família do pai como da mãe do recém-nascido, as mulheres da família do pai, assistem como testemunhas do parto.

É indispensável que perto do local onde decorre o parto se encontre um adivinho para ser consultado em caso de necessidade. O parto ou é normal (o que para todos é motivo de satisfação) ou é demorado e com complicações, o que obriga a determinar-se a razão disso.

Entre os Yao, parto difícil ou muito demorado, nunca se admite que seja determinado por motivos genéticos da parturiente, por má apresentação da criança, ou por qualquer outro motivo igualmente natural; se o parto for difícil é devido, inequivocamente, ao reprovável comportamento anterior de um dos progenitores ou, então, ao malquerer de qualquer pessoa, normalmente da família. Assim, há que determinar a razão das dificuldades.

Normalmente começam por convidar o pai do recém-nascido a confessar qualquer infidelidade conjugal que tivesse cometido durante a gravidez, convida-se também a lembrar de qualquer ofensa grave que tivesse cometido contra algum parente ou amigo e que pudesse ter determinado, da parte deste, o desejo de se vingar.

Sendo assim, vale à pena ressaltar que estas consultas ao pai do recém-nascido são, habitualmente, apenas formais, pois que, aos pecados da mulher é que se atribui com maior certeza os motivos das dificuldades no parto ou parto infeliz.

Se o parto não se resolve confessando o pai pecados anteriores ou não admitindo que os haja cometido, há que inquirir a mãe; esta é convidada a revelar se o filho que está para nascer é filho do marido ou se durante a gravidez manteve relações sexuais extraconjugais (infidelidade).

A parturiente começa, invariavelmente, por negar, mantendo a forma negativa, se isenta de culpa, mas acabando por confessar no caso contrário. Por qualquer motivo, o parto pode passar a decorrer normalmente sendo de admitir que a confissão alguma coisa tenha contribuído para isso, pois que a crença está de tal forma arraigada e 
impressionando profundamente que é natural operar-se, com a confissão, uma descontração favorável ao bem do sucesso do parto.

No caso da parturiente não confessar infidelidade conjugal a que se possam atribuir às dificuldades do parto, há que procurar a razão e assim, recorre-se a um curandeiro que possa indicar a pessoa que tivesse sofrido ofensa dela e que, por esse fato, mesmo inconscientemente, possa estar a dificultar os trabalhos do parto.

O curandeiro consulta os "ossinhos" e neles consulta o passado, determinado a pessoa ofendida, que pode ser o pai, mãe, avó, ou qualquer outra pessoa da família até mesmo estranha, sendo, no entanto, mais comum serem apontados parentes próximos como culpados.

O ofendido é convocado e convidado a levantar a maldição perdoando a ofensa, o fará, dizendo: se realmente a criança não nasce por causa da ofensa que a mãe me fez, eu peço a deus, todo poderoso, que nos ajude a velar bem como aos nossos antepassados, por esta minha (neta, filha, sobrinha, etc.), para que a criança nasça a fim de aumentar o nosso povo. Seguidamente é lhe apresentada uma cabaça ${ }^{15}$ com água, de que tira um gole e, depois de bochechar demoradamente, deita a água fora, querendo significar com isso que lavou todo o rancor que sentiu no dia que foi ofendido. $O$ cumprimento de todas estas formalidades demora, habitualmente, o tempo necessário a que o parto se resolva naturalmente.

Se assim não for e a criança nascer mortas ou ambas, tal desenlace é sempre atribuído ao fato de não se ter determinado, a tempo, a causa que impediu bom sucesso, de modo a esconjurá-lo.

A observância destes costumes tem impedido que muitas parturientes Yao frequentem as maternidades que o estado mantém, só as procurando em desespero de causa e, por isso, demasiado tarde.

Muitas mães podiam ser salvas se tivessem assistência clínica em tempo oportuno. Certamente que, com um pouco de compreensão e de transigência se podia

\footnotetext{
${ }^{15}$ São canecas feitas tradicionalmente onde essas comunidades usam para beber água, bebidas tradicionais, etc.
} 
conciliar o informal funcionamento das maternidades do Estado com arraigado formalismo do procedimento tradicional dos Yaos.

Após o nascimento, a mãe e o filho, ficam retidos dentro de casa até que o cordão umbilical caia - regra geral sete dias. Sendo durante todos estes dias esfregado com cinza, ou medicamentos hospitalares. O sétimo dia após o nascimento é festejado pela família e amigos.

O ponto culminante da festa é a distribuição, por todos os presentes, de pequenos bocados de carne assada e barrada com mel; é nesta cerimônia que é feita a primeira imposição de nome da criança: tratando-se do primeiro filho, geralmente é o nome do avo ou da avó paterna, se for mulher. A segunda imposição do nome é feita na altura da iniciação, é nesta festa do sétimo dia, ainda, que é rapado o cabelo da criança, pelo mwalimu ${ }^{16}$.

Se o parto resultou em nati-morto, no sétimo dia é feita, do mesmo modo, a cerimônia, com as limitações impostas pelo fato.

Em algumas localidades é permitido ao pai da criança que a visite durante sete dias de reclusão, mas apenas se durante o parto tiver ficado provado que não com eteu adultério que tivesse dificultado o nascimento.

No último dia de confinamento o marido é conduzido junto do filho e da mulher, pelas madrinhas desta e pelas mulheres casadas da família, e a criança passeada, em procissão, no meio de cantos e de danças. Nesse mesmo dia tem lugar a cerimônia de "kunkoposya mwanace mluli" 17.

Esta cerimônia começa pela apresentação a criança ao sol começando por dar um banho a criança, próximo da residência, água a que se adicionam folhas e raízes. O banho é dado pelo curandeiro ou por pessoa por si indicada e da água do banho é obrigada a beber uma galinha que depois é lançada para cima da palhota.

A criança ao colo do curandeiro ou de pessoa indicada, é passeada em redor da casa e pelos caminhos das imediações, especialmente pelos caminhos que cruzam, sendo banhada, de novo, em cada cruzamento. Juntamente, segue uma mulher com um

\footnotetext{
${ }^{16}$ Professor em Kiswahili, uma língua falada em Niassa, que é originária da Tanzânia.

${ }^{17}$ Significa retirar a criança de dentro da casa para ser apresentada ao sol e a lua.
} 
pilão, fingindo que pila, mas apenas para fazer barulho. O curandeiro dá de beber algumas gotas da água do banho, a criança, enquanto diz: "Tudo o que te derem a comer e achares que não é bom deves vomitar, tal como fez a galinha a quem foi dada água de banho". (AMARAL, 1990, p.62)

Há protesto do barulho do pilão, dirá: "Não te assustes com o que ouvires como não te assustes agora com o barulho do pilão que mal nenhum te faz: Seja o que for que vier por este caminho não te assustes, pois foste tu primeiro que por aqui passou". (AMARAL, 1990 p.63)

Acabada a cerimônia, o curandeiro é gratificado com um pano que envolve a criança, com a galinha que lançaram para o telhado da palhota e uma moeda de prata. Esta cerimônia encerra a iniciação da mulher.

Durante um período variável de 60 a 180 dias do nascimento da criança, o casal abstém-se de manter relações sexuais. Quando aparece o primeiro dente da criança, procedem, os casais constituídos, a um coito ritual a que chamam kunkunda mwanace $m e s i^{18}$. Quando na altura da dentição o pai não se encontra presente ou a criança é filho do adultério da mãe, ou ainda se é desconhecido o pai, procede-se à cerimônia.

Esta cerimônia consiste em convidar homem casado, conhecido como de bons costumes, para ter relações sexuais rituais com a mãe da criança que dá origem a cerimônia.

Esta cerimônia de "kulasisya" vai caindo em desuso, sendo substituída por outra que se processa da seguinte forma: o homem escolhido mantém relações sexuais com a sua própria esposa, após isso, sentando a criança nas pernas, banham-se em água a que são adicionadas infusões fornecidas pelo curandeiro.

A mãe da criança aguarda, fora da palhota, até que a cerimônia acabe. Terminada a cerimônia a criança é entregue a mãe e o casal gratificado com uma moeda certa quantia de dinheiro. O coito ritual é de purificação e também, segundo crêem, necessário para preservar principalmente a criança, contra a $n d a k a^{19}$.

\footnotetext{
${ }^{18}$ Quer dizer deitar água nas costas da criança.

${ }^{19}$ Refere-se as doenças relacionadas a malditação.
} 
A criança é aleitada ao peito da mãe, normalmente até aos dois anos de idade altura que costuma ocorrer à nova gravidez. Não ocorre qualquer cerimônia durante o desmame, sendo apenas usual consultarem o curandeiro para que faça o tratamento profilático da doença que designam cikasi, acreditam que é uma doença que pode atacar o pai e a criança que foi desmamada.

No pai, a doença é caracterizada por astenia profunda e rápido emagrecimento; na criança, por choro constante por crescimento desproporcionado da cabeça, de tal modo que dá a impressão de que se vai partir em duas. Além da profilaxia também se pratica o tratamento da doença depois de manifestada.

A prática sexual é interditada às mulheres durante as cerimônias da iniciação, durante o luto, no período menstrual e em período variável antes e depois do parto. A não observância desta interdição pode acarretar graves males entre os quais a doença que designam por ndaka caracterizada por edema generalizado, avultado no ventre.

Esta doença parece estar identificada como aquela a que os médicos dão o arrevesado nome de kwashiorkor, e é provocado pela carência de proteínas de origem animal. A interdição à prática sexual, nos homens, é limitada ao período de luto pela mulher ou pelos filhos.

A vida das crianças e adolescentes Yao decorre na povoação da mãe, em completa liberdade sob olhares compassivos dos mais velhos. Nunca um adulto castiga corporalmente uma criança e se tem de repreendê-la, fá-lo em voz pausada, paternalmente, encontrando sempre desculpa para as infantis diabruras.

"É vulgar, o adulto, depois de repreender a criança, voltar-se para o outro adulto que, por ventura estiver presente e dizer: coitados, são crianças, não sabem o que fazem, ou então, se a traquinice foi mais pesada, dizer estas crianças são insuportáveis, mas são crianças, coitadas, não sabem o que fazem, estão a precisar de ir na lupanda (circuncisão) para aprenderem a comportar-se"(AMARAL, 1990, p.65)

É típico dos Yaos, salvo quando não estão em perfeito juízo, não se exaltar, falarem em voz velada, perante alguém explosivo que fale aos gritos e que gesticule, 
mantém-se uma atitude de perplexidade e, em vez de se atemorizarem ou ficarem ressentidos, ficam com pena, pois consideram tal atitude uma lamentável falta de autodomínio, que só pena deve causar.

Para o casamento nos Yao existem formalidades para tal, como por exemplo, o homem deve ser circuncisado e a mulher de ter sido iniciada, por volta dos 16 anos de idade.

Os Yao uma vez que a maioria é muçulmana são polígamos, por tradição e por determinação do alcorão. Pois podem possuir quantas esposas puderem se a sua importância social consentir.

O Alcorão permiti a poligamia limitada e com algumas restrições sendo uma delas: pode ter 2 ou 3 ou 4 esposas, desde que todas sejam tratadas igualmente. Se o homem não for capaz de conviver com todas as esposas justamente, então este deverá se casar apenas com uma única. Porém a poligamia não deve ser vista aqui como o ideal. Em algumas regiões da África a poligamia existe por motivos morais e sócias, por existirem várias mulheres e poucos homens e uma mulher só é respeitada se estiver casada. (Fonte: amaivos.uol.com.br/amaivos09/.../noticia.asp? Acesso 4 Mar.2013).

Existe o divórcio nos Yao. Eis algumas motivações para tal:

- Impotência do marido.

- Esterilidade de qualquer dos cônjuges.

- Adultério da mulher.

- Maus tratos infligidos à mulher (violência doméstica).

- Convicção d e que o marido ou mulher praticam atos de feitiçaria.

- Manifesto desinteresse da mulher pelos afazeres domésticos.

- Desinteresse continuado do marido no apóio que deve à mulher, nos trabalhos agrícolas e outros. 
- Repetidas e longas ausências do marido, do lar conjugal, sem que no regresso seja portador de bens adquiridos que possam justificar essas ausências.

- Certas doenças graves contraídas por qualquer dos cônjugues (lepra, tuberculose, demência, etc.).

- Falta de respeito de um dos cônjugues.

Convicção de que, marido ou mulher são portadores de ligango, doença que, segundo crêem, tem como sintoma e efeito o fato de provocar o nascimento de filhos mortos, dentre outras. Antes da islamização, os Yao não admitiam a existência da morte natural, excetuando a que ocorresse em combate ou por extrema velhice, se alguém morre, é porque alguém o matou, diziam, Deus só recebe o homem porque o seu semelhante o expulsou da terra.

O falecimento de alguém estabelece estado de impureza, não só entre todos os membros da sua matrilinhagem, quer vivam próximo quer afastados, como também, entre familiares ou simples vizinhos que tivessem convivido recentemente com o falecido, geralmente toda povoação, pois que, como padrão de convívio, estabelecem o fato de terem utilizado a mesma fonte de água ou pilado no mesmo pilão.

Um dos mais estranhos costumes desenvolvidos nos mais recuados tempos da história da humanidade foi o da automutilação. Os homens começaram a cortarem-se, a praticar excisões nos dentes, nas orelhas, no nariz e em outras partes do corpo ligando os tais atos toda a sorte de ideias supersticiosas. São vestígios desses esquisitos costumes, os ritos de circuncisão entre os monoteístas judeus e muçulmanos e entre os bantos, supondo-se ser a prática da circuncisão por estes últimos, autônoma do costume semítico.

A origem segura da prática da circuncisão entre os Yao não é conhecida, podendo, no entanto, sugerir algumas hipóteses. A que mais seduz é a de que, sendo as cerimônias da iniciação, tanto masculina como feminina, a sua principal instituição cultural e o fator mais importante e que mais vai influênciar a vida do homem e da mulher, era necessário associar-lhe um ato vivido. 
E, tendo atenção à finalidade das cerimônias, que é a de instruir o homem e a mulher nos costumes, tabus, etiqueta e, de procriar (aumentar a família), preocupação dominante dos Yao, para quem uma numerosa família é, em última análise, a riqueza mais valiosa, nada mais vivido do que lhe dar início com uma ação direta sobre os órgãos da reprodução.

E assim, é que a circuncisão teria sido o primeiro ato das cerimônias da iniciação masculina e a clitoritomia e a desvirginação ritual, da iniciação feminina. Naturalmente que se trata apenas de uma hipótese, mas muito defensível.

Tanto mais que se para a circuncisão ainda se pode alegar motivo de ordem higiênica, para a clitoritomia (já em desuso) nem isso se pode invocar; é um ato tanto mais desnecessário quanto é certo que nunca ninguém se preocupou nem preocupa saber se as iniciadas, quando submetidas ao ritual da desfloração, eram virgens.

Estejam ou não virgens o ritual cumpre-se, o que nos leva, naturalmente, a concluir que a finalidade do ato não é realmente romper o hímen, o que utilidade nenhuma teria, mas apenas exercer sobre o órgão um ato simbólico, o que corrobora com a nossa hipótese.

A cerimônia de iniciação, longas, complicadas, cheias de ritos superstições, de magia e de tabu, representa, a despeito disso, a manifestação cultural mais saliente do povo Yao. Nelas são ministrados ensinamentos de comportamento familiar e social, de história de origem da linhagem, de conceitos morais e religiosos, de bondade, generosidade e de fraternidade.

Os ensinamentos são proporcionados por forma tão sugestiva e rodeados de mistérios tão profundo que marcarão indelevelmente o iniciado. Têm, além disso, a vantagem de reforçar a solidariedade na povoação, pois, os neófitos de cada ano, provenientes de várias mbumba e/ou famílias, ficam a constituir uma espécie de irmandade. A coesão familiar é também fortalecida já que as cerimônias são vividas, por todos, com grande intensidade.

O islamismo, com tradições de ritos de circuncisão, não se opôs aos praticados pelos Yao, procurou sim, infiltrar-se neles de modo a influenciá-los no sentido da sua doutrina religiosa, o que conseguiu, mas respeitando as práticas ancestrais em uso, pois 
o islamismo é uma religião simples e compreensível, feita de bondade, generosa e de sentimento cavalheiresco.

Existem políticas públicas em benefício das pessoas com deficiência. Algumas das deficiências são comuns de se encontrar por lá, por exemplo, deficientes visuais, auditivos e físicos e principalmente nas cidades capitais. Na zona rural essa realidade é diferente. Provavelmente porque esses não tenham acesso a essas politicas. Ou mesmo porque esse grupo é mais conservador que os que vivem nas cidades. Este último aspecto me faz levantar um questionamento:

Será que os aspectos culturais têm alguma influência para que estas crianças não estejam inseridas no meio social? Esta hipótese tem muito a ver com o modo de se lidar com os fatores naturais, dando sempre um significado a tudo que acontece com os povos da cultura Yao, como foi descrito ao longo do texto. Retorno alguns práticas dos Yao só para dar continuidade essa discussão, por exemplo:

A mulher grávida deverá abster-se de tomar refeições juntamente com mulheres que não mantenham uma vida sexual normal, pois se acredita que o contato com mulheres desregradas ${ }^{20}$ pode determinar um parto infeliz, portanto "o parto ou é normal que é motivo de satisfação, ou é demorado e com complicações, o que obriga a determinar-se a razão disso" (Amaral, 1990, p.59). Buscando sempre essa razão dentro da própria cultura.

Se assim não for, e a criança nascer morta ou a mãe morrer durante o parto, ou ambas as situações, tal desenlace é sempre atribuído ao fato de não se ter determinado, a tempo, a causa que impediu o bom sucesso do parto, de modo a esconjurar os maus espíritos.

A observância destes costumes tem impedido que muitas parturientes Yao frequentem as maternidades que o Estado mantém, só as procurando em desespero de causa e, por isso, demasiadamente tarde. Muitas mães podiam ser salvas se tivessem assistência clínica em tempo oportuno.

Certamente que, com um pouco de compreensão e de transigência, se podia conciliar o formal funcionamento das maternidades do Estado com o arraigado

\footnotetext{
${ }^{20}$ Refere-se a mulheres solteiras, que a vida sexual delas é feita fora do casamento.
} 
informalismo do procedimento tradicional dos Yao. Enfim, as questões relacionadas às dificuldades do parto, que para a sociedade ocidental são encaradas por via de explicações genéticas e outros fatores biológicos, para os Yao estão relacionados às suas mitologias.

Amide, no trabalho intitulado Wayao'we no conhecido Niassa, faz a seguinte afirmação: "o mito tem um caráter de verdadeira fé de um povo o qual aceita, docilmente, o que se deve pensar, os magnos problemas do mundo e da vida, do sobrenatural e dos seres humano" (AMIDE, 2008, p.82).

Entre os Yao, a explicação mitológica para os acontecimentos acima pontuados são comumente o que pode parecer "irracional" aos olhos ocidentais.

Em contrapartida, segundo Adorno e Horkheimer, na "Dialética do Esclarecimento", o mito já contém em si o esclarecimento, uma vez que procura denominar e explicar os acontecimentos vivenciados por uma comunidade, assim como, dialeticamente, o esclarecimento, ou seja, a tentativa do homem entender o mundo de forma científica e racional acaba por reverter-se em mitologia, ao passo que diante da separação sujeito e objeto, intensificada na sociedade capitalista em voga, as relações econômicas tornaram-se tão abstratas que as forças sociais funcionam de forma análoga a mitologia.

Os filósofos ainda ressaltam: "a causa da recaída do esclarecimento na mitologia não deve ser buscada tanto nas mitologias nacionalistas, pagãs e em outras mitologias modernas especificamente idealizadas em vista dessa recaída, mas no próprio esclarecimento paralisado pelo temor da verdade" (p.13).

Os Yao ao vivenciarem sua cultura, como parte do seu cotidiano e em consonância com os seus ideais, por mais que aos olhos das sociedades ocidentais seja algo ultrapassado, estão buscando uma racionalidade para as questões que os atravessam.

Dessa forma, nosso objetivo não é valorizar o esclarecimento em detrimento do mito, ou vice-versa, mesmo porque quanto mais racional a nossa sociedade se torna, mais elementos irracionais ela incorpora, como o medo da identificação com o que gera marginalização social, por exemplo. Por isso, não é nossa pretensão levar um 
esclarecimento científico para esta comunidade, às mudanças devem ser internalizadas e amadurecidas de forma endógena.

O que não nos impede de avaliar e refletir sobre esta questão: "Se o esclarecimento não acolhe dentro de si a reflexão sobre o elemento regressivo, ela está selando o seu destino. Abandonando a seus inimigos a reflexão sobre esse elemento destrutivo do progresso, o pensamento cegamente pragmatizado perde seu caráter superador e, por isso, também sua relação com a verdade" (HORKHEIMER \& ADORNO, 1986, p.13).

A partir da comparação da situação da inserção das crianças com deficiência na sociedade brasileira, acreditamos que existe um movimento de campanhas e programas beneficiando as pessoas que as têm, o que mostra que de fato existe um movimento para que elas estejam inseridas no meio social.

É claro que, em alguns casos, elas continuam segregadas em escolas especiais. Em outros, mais particularmente relacionados ao ambiente familiar, aparecem como "anjos" ou mesmo são ressaltadas apenas as capacidades destas crianças, ignorando as limitações intrínsecas de sua faixa etária, presentes em qualquer criança, seja ela deficiente ou não, colocando-as numa situação estereotipada.

Se até num país como Brasil, e dentro das cidades em Moçambique onde a deficiência vem sendo abordada com certa constância, existem atitudes estereotipadas frente esta deficiência, qual seria então o futuro de pessoas com deficiência na comunidade Yao?.

Fica-se com uma sensação de incertezas sobre qual seria o melhor lugar para estas pessoas porque o preconceito é visto em várias dimensões, em nível social, psicológico e individual, desenvolvendo-se no indivíduo através de seu processo de socialização, ou seja, "aquilo que permite o indivíduo a se constituir é também responsável por ele desenvolver ou não desenvolver o preconceito" (CROCHÍK, 1995, p.13).

Algumas atitudes dos Yao frente a uma pessoa com deficiência podem pode estar relacionadas aos fatores descritos acima. O que achamos positivo na postura desta comunidade é que, para ela, essas crianças têm um significado, sendo que uma criança 
deficiente é fruto de um malquerer de alguém, ou de um reprovável comportamento de um dos seus progenitores, a convicção de que marido ou mulher são portadores de "ligango", doença que, segundo creem, tem como sintoma e efeito o fato de provocar o nascimento de filhos com alguma "anormalidade", mortos, dentre outras.

No entanto, na sociedade brasileira as crianças com deficiência pertencem a um não lugar, ou seja, embora não sejam completamente margizalizadas, devido a um processo de inclusão social, elas também não estão inseridas socialmente, pois suas limitações são supervalorizadas em detrimento de suas habilidades. "A identidade social da pessoa com deficiência acaba então sendo construída a partir do confronto de sua diferença e o modelo da normalidade, segundo interesse e definições de outras pessoas mesmo sob proteção de familiares e instituições” (SUAD 2003, p. 112).

No entanto, apesar de as pessoas com qualquer tipo de deficiência nas sociedades tradicionais serem vistas como fruto de pecado, o preconceito perante elas é, na nossa percepção, menor do que as que estão inseridas na sociedade ocidental, porque, afinal, no primeiro caso elas têm um lugar e um significado. Existe um preconceito em torno da explicação mítica, porém esta explicação está presente em sociedades tradicionais assim como em sociedades ocidentais.

A postura dos Yao perante isso, por exemplo, ao associar pessoas deficientes com algo da sua história, ao mesmo tempo eles estão tornando o objeto como parte dessa mesma cultura. Na sociedade capitalista ocidental, o indivíduo é definido pelo trabalho, pois, a partir de sua profissão, ele se insere na vida social e torna-se parte integrante da sociedade. O seu poder de consumo também não pode ser descartado no capitalismo avançado.

Estas atitudes são observadas em sociedades primitivas como Freud coloca em seu livro "Totem e Tabú", e que em sociedades ocidentais também observamos situações parecidas.

Sengundo Wundt, um dos pesquisadores que busca a origem do conceito de tabu, se tentarmos entender o significado da palavra tabú, então ninguém escaparia dos efeitos. 
Segundo Freud, a palavra tabú denota tudo a partir do pessoal, misterioso atributo, proibições vindas do mesmo atributo, mas também o sagrado, perigoso, impuro, enfim, algo acima do normal. Ainda este autor nos diz que ao entrarmos em contacto com o tabu, automaticamente, conectamos aos fantasmas, espíritos etc. Assim, é importante se preocupar com o enigma tabú por vários factores, eis um deles: Porque uma explicação do tabú pode fazer entender a origem obscura do nosso próprio “imperativo categórico”. (FREUD, 1999, p.32) 


\section{CAPÍTULO 2}

O presente capítulo discutirá a relação família-deficiência: concepção de família, o impacto provocado pela presença da deficiência e as formas de superação.

\subsection{Conceito de Família:}

A família é sem dúvidas um espaço privilegiado dos que a compõem, e ao mesmo tempo é um centro de contradição, mas nem por isso ela deixa de ser importante. Porque é dentro dela onde a pessoa dá os seus primeiros passos para se tornar um ser social, assim acontece por meio das relações, estabelecidas, dentro de um agregado familiar, ou seja, entre pais/ filhos e vice-versa e entre irmãos.

A família é um campo de intersecção entre o real e o psíquico, uma tessitura que, em seu arranjo de parentesco e nos significados que atribui a cada um dos indivíduos que a compõem, sofre a determinação de uma história sociocultural na qual se estabelece e que atravessa e, ao mesmo tempo, é constituída na interação afetiva entre os membros. (MANDELBAUM, P.107,2012)

Através dela, constitui-se como lócus de formação da personalidade da criança, principalmente a relação mãe - bebe, conforme Freud, citado por Reis. Todavia, alguns autores, como Reis apontam que a constituição familiar muda historicamente, existindo vários modelos como a família aristocrática, camponesa, burguesa e proletária. (REIS, 1989, p.106).

Mudam também as relações e os papéis dentro da família. As relações no interior da família nem sempre são harmoniosas e por vezes são marcadas por conflitos e crises que fazem parte do desenvolvimento desse grupo social. No entanto, o que não pode ser negado é a importância da família tanto ao nível das relações sociais, nas quais ela se inscreve, quanto ao nível da vida emocional de seus membros. (REIS, 1989, p.99).

Por outro lado, ainda dentro desta instituição familiar como aponta Reis, foi onde teve o inicio, ao processo de divisão do trabalho por sexo, que determinam a estrutura família. 
Conceituando família, segundo Reis, 1989 se baseia, em três aspectos fundamentais o seguinte: $1^{a}$ Família, não é algo natural ou biológico, mas é criado pelos homens para responder as necessidades sociais; $2^{\mathrm{a}}$ Constitui-se em torno de uma necessidade material a reprodução, o que não quer dizer que a questão da reprodução, ocorra dentro de um determinada forma de família; $3^{\text {a }}$ Exerce uma função ideológica,ou seja, além da reprodução biológica também promove sua reprodução sua reprodução social. (REIS, 1989, p.102).

A instituição familiar é uma trama complexa sem dúvidas, que não se fecha a um pequeno contexto. Ela se abre ao meio social, acompanhando deste modo o movimento e as mudanças, que vão surgindo neste outro contexto mais amplo.

Na sociedade ocidental contemporânea, como aponta MANDELBAUM (2012 P. 108), o termo família remete, de maneira geral, à família nuclear, composta por par heterossexual casado, monogâmico, unido por laços sentimentais, por cooperação econômica, contínua e por um interesse comum ligado ao cuidado da prole. Este tipo de família está fortemente ligado ao modo como até aos dias de hoje ela é estruturada.

O termo família é denominado e conhecido como um grupo de pessoas normalmente ligado por relações de afeto ou parentesco ${ }^{21}$.

\subsection{Família e deficiência:}

Família é responsável pela transmissão de tudo aquilo o que a vida oferece, até o suporte emocional para as crianças. Porém essa responsabilidade aumenta quando a criança é deficiente, pois a criança necessita de um maior envolvimento em seus cuidados e em sua estimulação.

Para tal, viver-se-á vários momentos, no estabelecimento de relação com esse filho, que passará por várias fases para que se encontre de fato melhores alternativas para que essa estimulação ocorra.

Há várias fases enfrentadas pelos pais de filhos com deficiência: fase de choque; fase de negação; fase de reação e fase de adaptação; esta última é fundamental

\footnotetext{
${ }^{21}$ Boletim da República de Moçambique: 1ª serie. Nr. 23, supl, de 10 de junho de 1997,
} 
porque é o momento que os pais se tornam mais realistas e saem em busca de soluções para atender e ajudar imediatamente as necessidades do filho deficiente.

Este é um dado importante a se ter em conta quando se fala da participação dos pais na vida de filhos com necessidades especiais, ainda assim, não devem generalizados, pois em algumas famílias isso pode não ser observado.

Quando os pais aguardam a chegada de um filho é cheio de expectativas e planos. Um filho com deficiência pode acabar com essa expectativa gerada por eles, ai o sentimento perante a ele fica difuso. Este sentimento, por sua vez, poderá acarretar sérias atitudes, que podem ser estimuladoras ou não. Um dos trabalhos mais significativos sobre a família e deficiência, foi escrito, por Ligia Assunção Amaral.

Amaral (19950 discute um aspecto muito importante : a ambivalência de sentimentos presente na relação entre família e a criança com deficiência. Isto é amoródio, alegria-sofrimento, aceitação-rejeição, confiança- descrédito. Estes sentimentos acontecem muitas das vezes simultaneamente e vai oscilando entre aceitação e rejeição, euforia e depressão. Outros aspectos apontados por esta autora quando se fala da chegada de um filho com deficiência são:

\section{- impacto da deficiência na constelação familiar}

- situação de crítica e crise

\section{- luto e superação do luto (depende da dinâmica familiar)}

Estes três aspectos são fundamentais quando se está frente a uma criança com deficiência, pois em muitos casos estão presentes e vão oscilando de uma fase para outra dependendo de cada situação.

Quando se fala do impacto da deficiência na constelação familiar, é o choque que se tem no primeiro momento, em que a família recebe a notícia de que o filho teria nascido com uma deficiência. Segundo Amaral 1995, a situação de crise tem como eixo dois pontos fundamentais: fracasso e ambiguidade, que para esta seriam componentes essênciais, na configuração de crise.

Ou seja, partindo-se do pressuposto que toda situação nova, desconhecida, traz em seu bojo a ambiguidade, pode-se 
afirmar que é o fracasso em superá-la que irá configurar a passagem da situação crítica para a crise propriamente dita. (AMARAL, P.74, 1995).

Portanto, o fracasso na superação e a ambiguidade surgem pela impossibilidade de adaptar-se a situações novas. A chegada de um filho deficiente dentro da família, muitas das vezes é vista como um evento completamente novo e inesperado. Nisso, para que se torne possível receber o filho real faz-se, então, necessário viver o processo de luto daquele filho perdido.

Contingencias individuais e inter-individuais, como a própria dinâmica familiar definem de alguma forma a maneira e o tempo de elaboração desse luto, bem como o conjunto de reações a isso relacionado.

Dentre essas contingências pode-se assinalar, com Omote (1980), que o impacto familiar depende especialmente de seis variáveis: "história anterior da família e seus dinamismos, o sentido por ela atribuído a deficiência em pauta;o grau de comprometimento no caso de seu filho; a forma como lhe foi transmitida a noticia ; o nível socioeconômico familiar e as expectativas em relação a prole e/ou em relação a esse filho em particular". Citado por (AMARAL, 1995, P.78).

Estes dois aspectos: fracasso e ambiguidade levariam a passagem da situação crítica para a de crise propriamente dita. Que levariam a três possíveis caminhos: não resultar em crise, encaminhar-se para a formação de uma crise larvada e desembocar na crise propriamente dita. (AMARAL, 1995, P.75).

Por outro lado, quando se fala de questões ligadas a deficiência, tem que se ter em conta a estas duas situações: criticas previsíveis e imprevisíveis.

No caso de deficiência congênita ou precoce de um filho, esse e, obviamente, um acontecimento traumático e imprevisível do ponto de vista dos pais. Nesse mesmo caso, do ponto de vista do filho, situações críticas previsíveis podem ser aprioristicamente pensadas como agravadas, dependendo do quadro, no que se refere a desenvolvimento físico, psíquico ou social. (AMARAL, 1995, P.77). 
Ainda diante da deficiência precoce, como foi apontando anteriormente, logo a prior, lidamos com a realidade, ou acionamos os mecanismos de defesa que consiste na eliminação de uma fonte de insegurança, perigo, tensão ou ansiedade. (AMARAL, 1995, P.114).

\subsection{A pessoa com deficiência no contexto social:}

A inserção da pessoa com deficiência, no meio social é , sem dúvidas, um grande desafio e ao mesmo tempo um caminho para a superação dos limites que a própria deficiência pode trazer .

O contexto social, segundo Amaral, reduz a distância da segregação entre as pessoas com ou sem deficiência, o que não quer dizer que seja garantia de que possa existir interação entre eles, pode sim existir uma segregação menos explícita, mas nem por isso menos prejudicial. (AMARAL, 1995, P. 103).

Só pelo fato da pessoa deficiente compartilhar o mesmo espaço, suscita nas pessoas sem deficiência uma curiosidade. Essa curiosidade passaria necessariamente, pelo desejo de conhecer mais e melhor o "desconhecido".

Portanto, "a criança nasce em mundo repleto de significações, conceitos e estruturas constituídas pelo grupo social”. É pela apropriação dessas significações que a criança vai se incorporando ao enredo que faz dela uma pessoa. "(BATISTA \&FRANÇA, 2007)".

Portanto, a inserção da pessoa deficiente no contexto social fará com que essas significações sejam resignificadas, provocando mudanças nessas estruturas .

Nessas circunstâncias, a pessoa com deficiência, a família e a sociedade se influenciarão mutuamente. À medida que a família e sociedade necessitam construir um novo conhecimento sobre a pessoa com deficiência, desenvolvem padrões de interação e um conjunto de ações favoráveis aos seus membros, sejam eles deficientes ou não. (BATISTA \&FRANÇA, 2007). 


\subsection{A pessoa com deficiência no contexto familiar:}

Foi realizado um levantamento na base de dados Scielo com a palavra deficiência e família, onde foram selecionados 35 artigos mais relevantes publicados entre 1999 a 2012, dentre os quais, nove se referiam à família, pais e filho / criança com deficiência; três aos profissionais da saúde e família com filho com deficiência e os restantes abordavam assuntos diversos sobre a deficiência.

Este levantamento teve como objetivo, obter informações atuais em relação ao que já foi escrito, sobre a família e um filho deficiente. Trata-se dos seguintes artigos: (BARBOSA, at. al. 2012); (AZEVEDO, G. R. \& SANTOS, V. C. G.2006); (GÓES F. A. B. 2006); (GOITEIN, P. C. \& CIA, F. 2011); (BUNHARA, F. \& PETEAN, E. B. L. 2008); (PETEAN, E. B. L.; \& MURATA, M. F. 2000); (Fiamenghi G. A. \& Messa A. A. 2007); (SILVA, N.L.P., \& DESSEN, M. A. 2001)’; (CHACON, N. C. M. 2011).

$\mathrm{Na}$ nestes artigos sobre a deficiência e família, o assunto que mais se destacou foi á questão, do impacto que uma criança com deficiência gera no seio familiar e quanto os sentimentos são contraditórios e oscilam constantemente, e que esta reação, depende muitas das vezes, porém nem sempre, da forma como a notícia é transmitida a família, no primeiro momento.

O estudo das relações entre a família e a pessoa com deficiência é importante para entender o quanto o relacionamento com o filho deficiente no seio familiar, varia dependendo de cada situação e de cada família e que de forma alguma devem ser generalizados.

Quando se aborda a questão do impacto na família são citadas a desilusão e quebra de expectativa. Isto é, a atenção é virada à deficiência e não a própria criança. Um filho com deficiência pode ou não suscitar um impacto negativo no seio da família, porém ela exigirá da família uma reorganização, no sentido de atender certas necessidades que a sua condição deficiente/deficiência poderá trazer.

A mãe, segundo pesquisas, é a principal afetada, isso porque ela é responsável peos cuidados dos filhos, seja ela com ou sem deficiência. Já quando se fala do pai, o aspecto trazido, com frequência, foi à ausência da figura. 
Segundo (CHACON, 2011), que fez um levantamento 382 artigos, na Revista Brasileira de Educação Especial, de vários temas em que alguns tratavam de família analisavam apenas relatos das mães.

Este autor, afirma que durante a pesquisa sentiu a ausência total de trabalhos que falassem da figura do pai. Sua pesquisa portanto foi feita com dez pais e analisa suas percepções em relação ao filho com deficiência. Um dado importante que não é excluído da percepção dos pais é baixa expectativa em relação à independência dos filhos.

Em outro levantamento feito pelo mesmo autor (CHACON, 2011) na Revista de Psicologia, foram encontrados 46 sendo que apenas dois tratavam de Educação Especial e pai.

Com esta pesquisa fica visível que a participação dos pais na vida dos filhos e em específico de um filho com deficiência é menor em relação às mães

GOI TEIN \& CIA (2011) aponta que mesmo com a presença da mãe seja mais visível, na vida de uma criança deficiente, ambos os pais se frustram e se sentem responsáveis pela condição da criança. Porém, as mães mostram-se mais fragilizadas, chegam até a entrar em depressão, por ter uma maior responsabilidade pelos cuidados e pela educação dos filhos com deficiência, quando comparadas com os pais.

Uma vez que, a presença de um filho com deficiência na família exige desta uma reorganização na dinâmica familiar, ela pode ser marcada por um desgaste excessivo, causando muito sofrimento por parte do cuidador. É comum encontrar pais que abrem mão da sua vida para viver em função do seu filho principalmente quando não existe um suporte técnico-institucional.

O artigo de AZEVEDO \& SANTOS, (2006) mostra este aspecto a partir de uma pesquisa onde analisa os significados do cuidar para cuidadores/ familiares que compartilham o cuidado domiciliar de pessoas com deficiência física por uma lesão medular traumática. Esta pesquisa é importante para se pensar a questão do sofrimento do cuidador. O sentimento de impotência diante do futuro tão aflitivo e de incompetência para tarefas específicas foram um dos aspectos trazidos nos relatos dos cuidadores que participaram desta pesquisa. 
MESSA \& FIAMENGHI (2010) apontam que os conflitos familiares não surgem em resultado direto da deficiência, mas em função das possibilidades de a família adaptar-se ou não a essa situação.

Segundo os autores acima citados: a visão do senso comum de que uma criança deficiente irá, necessariamente, produzir conflitos na família não tem comprovação em pesquisas. Famílias com crianças deficientes são uma população de risco, mas isso não quer dizer que esse risco irá concretizar-se. (MESSA \& GERALDO, 2010).

Este aspecto contrariar a ideia de que uma criança com deficiência, representa um quebra de expectativas, abalando a estrutura familiar.

\subsection{Família e profissionais de saúde:}

Os artigos de: MILBRATH, M. J. S. et.al. (2011); CASTRO, S. S. et. al., (2011); LEMES, L. C. \& BARBOSA, M. M(2007), abordam a questão da família e filho com deficiência.

MILBRATH, M. J. S. et.al. (2011), aponta o quanto é importante uma linguagem adequada, no dialogo entre profissional de saúde e o usuário dos serviços de saúde. A linguagem adequada está atrelada a não uso de linguagens técnicas que muitas das vezes são incompreensíveis aos usuários e dotadas de força. Portanto o uso da linguagem adequada é fundamental tal como o acompanhamento a essas famílias, principalmente nos primeiros momentos. Portanto comunicação, bem como a interação entre a equipe de saúde e a família é essencial para a formação do vínculo entre a criança e a família como para manutenção da saúde mental (psíquica) dessa.

A pesquisa, BATISTA \& FRANÇA, 2007 trata da relação do profissional de saúde com a família, focalizando-se mais em processo de superação e o quanto esse processo está determinado a sua forma como os profissionais de saúde comunicam à família sobre o estado da criança. Estas questões são importantes nesse primeiro momento, pois os desafios maiores ainda surgirão. Entretanto, a maneira como cada família lida com esse evento, influenciará, decisivamente na construção da identidade do grupo familiar e, consequentemente, na identidade individual de seus membros. 
O processo, de superação é um momento importante e vivido no seio da família e que passa pelas seguintes fases: negação, adaptação e aceitação, como apontam. BATISTA \& FRANÇA, 2007.

Portanto quando se trata da questão da deficiência e família, tem que se ter em conta vários momentos alguns deles apontados ao longo do texto, em que um é determinado por outro muitas das vezes. Mesmo que vários autores apontem que na maioria das situações, a reação é negativa, tem que ter o cuidado de não generalizar, pois os casos são diferentes dependendo de vários fatores: situação econômica, fatores culturais, religiosos, e muitos outros. 


\section{CAPÍTULO 3}

O presente capítulo irá abordar o método que foi utilizado na pesquisa.

\subsection{Pesquisa tipo etnográfico:}

Tendo em vista os objetivos propostos, a pesquisa do tipo etnográfico foi considera a mais adequada para levar a cabo o estudo. Segundo André "etnografia é um esquema de pesquisa desenvolvido pelos antropólogos para estudar cultura e a sociedade e consiste em estudar e fazer uma descrição da cultura, hábitos, crenças, valores, linguagens e significados de um grupo social”. ANDRÉ, (2003, p.27-28).

Uma das características principais deste método é a observação que permite ao pesquisador analisar o fenômeno estudado em vários ângulos, sejam eles expressos pela linguagem ou pelas ações. Um das questões importantes que se deve ter em conta quando se fala do método etnográfico é a permanência do pesquisador no campo por um longo tempo.

Nesta pesquisa usou-se o método do tipo etnográfico, que consistiu em adaptar a etnografia, porém passou necessariamente pelo uso da técnica de observação participante, entrevistas semi-estruturadas que são aspectos diretamente ligados à etnografia.

A observação participante suscita no pesquisador uma grande capacidade de interação com o contexto estudado, afetando-a e sendo por ela afetado.

“A observação participante é uma das técnicas muito utilizada pelos pesquisadores que adotam a abordagem qualitativa e consiste na inserção do pesquisador no interior do grupo observado, tornando-se parte dele, interagindo por longos períodos com os sujeitos, buscando partilhar o seu cotidiano para sentir o que significa estar naquela situação” . (QUEIROZ, at. al.2007). 
Para que de fato este método atinja os seus objetivos, o pesquisador deve ficar em constante interação com o fenômeno estudado, participando ativamente em todas as atividades que envolvam o objeto pesquisado.

O pesquisador deve estar em constante interação com o objeto pesquisado. Ele é o instrumento principal na coleta dos dados, dando ênfase naquilo que está ocorrendo no processo e não no produto final, a preocupação com o significado que as pessoas atribuem a si mesmas, as suas experiências e o mundo e o tempo do pesquisador no campo, que pode variar muito.

Estes são alguns aspectos importantes a se ter em conta quando se fala da pesquisa do tipo etnográfico, que consiste na "descoberta de novos conceitos, novas relações, novas formas de entendimento da realidade" (ANDRE, 2003, p.30).

Isto passará necessariamente pela inserção do pesquisador no meio onde se encontra o objeto de estudo observado, de maneira que ele se torne parte deste, interagindo com o grupo em vários momentos, no período em que este estiver no campo, partilhando suas experiências, de forma a encontrar o seu pertencimento naquele contexto.

Este exercício de observação requer do pesquisador muito cuidado em relação a sua postura logo no início, de maneira que ele seja aceito pelo grupo pesquisado, "Nos primeiros dias de observação participante, por exemplo, o investigador fica regra geral um pouco de fora, esperando que o observem e aceitem" (BOGDAN \& BIKLEN, 1999, p. 125). Esta etapa consistiu em observação das atividades do dia a dia da família que envolve o objeto estudado, com objetivo de levantar mais dados.

\subsection{Procedimentos de coleta de dados:}

A coleta de dados foi realizada por meio de observação da rotina da família com um filho com deficiência intelectual e também através de entrevistas.

\section{a) Observação}

A coleta de dados por meio de observação foi realizada junto a uma família com jovem com deficência intelectual. A família, moradora de Sanga, foi localizada ao acaso durante a viagem de retorno de Mavago. 
Para a realização do trabalho de observação contou-se com o auxilio de uma interprete vizinha da família.

\section{b) Entrevistas}

As entrevistas foram semi-estruturadas para que os participantes deste processo se sentissem a vontade em esplanar vários aspectos que inclusive não estavam previstos (MYNAYO, 2006, p. 263).

Portanto, as entrevistas foram anotadas um caderno de campo. Segundo Bogdan e Biklen "As boas entrevistas produzem uma riqueza de dados, recheados de palavras que revelam as perspectivas dos respondentes".

As transcrições estão repletas de detalhes e de exemplos. "Um bom entrevistador comunica ao sujeito o seu interesse pessoal, estando atento, acenando com a cabeça e utilizando expressões faciais apropriadas" (BOGDAN \& BIKLEN, 1999, p. 136).

Os conteúdos destas entrevistas foram organizados e classificados de acordo aos objetivos da pesquisa. Para efetivação desta etapa usou-se um guião de entrevista pré-definido para cada participante envolvido, contou-se com a ajuda de um interprete uma vizinha no caso, visto que a família não falava português, apenas Yao.

A partir das entrevistas procurou-se buscar, as suas impressões sobre pessoas com deficiência. O trabalho foi realizado em Lichinga e em Sanga.

Participaram os seguintes entrevistados: Líder tradicional (Régulo), Parteira, curandeiro e agente da ação social.

A parteira foi indicada pelo Hospital Provinca de Lichinga. Com sua ajuda foram indicados e localizados o líder tradicional e o curandeiro. O agente da Ação Social foi idicado pela Direção Provincia de Lichinga.

\section{d) Instrumentos:}

Roteiros de entrevistas e de observação. 


\section{e) Recursos:}

Cadernos de anotação, esferográficas.

\subsection{Procedimento de análise dos dados:}

Para análise dos dados, foram selecionadas quatro categorias de análise, a partir dos relatos da família, questões observadas dentro do campo e entrevistas efetuadas aos agentes envolvidos: Família (caracterização, relação, rotina); Participação/exclusão de Bernardo na rotina e na vizinhança; Como a mãe explica a origem da doença; Relação pesquisadora-família-Bernardo. 


\section{CAPITULO 4}

\subsection{Resultados}

Tendo em vista os objetivos propostos nesta pesquisa, a coleta de dados foi realizada em Moçambique, na Província de Niassa.

Foram realizadas duas viagens. A primeira, em 2011, teve por objetivo buscar a indicação e o contato de uma família para realização da pesquisa. Por intermédio de um técnico do Conselho Municipal, tive a indicação de uma família que residia em Mavago.

Em sua companhia fomos à busca da família, porém não a encontramos. Segundo informação dos moradores vizinhos, a família tinha ido à machamba. Como o tempo que eu dispunha era curto, não pude esperar e retornei ao Brasil, mas satisfeita por saber que havia conseguido pelo menos a indicação de uma família.

Retornei a Moçambique em outubro de 2012, indo a Mavago com a expectativa de encontrar a família indicada pelo técnico do Conselho Municipal. Mais uma vez, eles não se encontravam; os vizinhos informaram que a família havia se mudado para outra aldeia. Como naquele momento não tinham mais informações sobre a família, retornamos uma semana depois, mas os vizinhos não conseguiram localizar a família.

Fui tomada por uma aflição desesperadora, visto que o tempo já estava ficando escasso. Eu não tinha noção de onde encontrar outra família para participar da pesquisa. De volta à cidade de Lichinga, onde eu residia, fizemos uma parada rápida em Sanga, um distrito que também é predominado por Yaos.

Nessa parada, nem tive vontade de sair do carro, pois estava cansada da viagem e frustrada. Enquanto as pessoas que me acompanhavam saíram do carro para pegar água, permaneci e fiquei e pensando no que iria fazer diante daquele imprevisto. De repente aparece um rapaz de aparentemente de 15 anos, que me chamou a atenção, ficou parado na janela do lado do motorista e ficou olhando para mim, sem dizer nada.

Eu falava com o rapaz, tentei cumprimenta-lo, mas ele ficou quieto sem responder. Na expectativa que ele tivesse alguma reação, peguei a máquina fotográfica e 
tirei uma foto dele, mas ele continuou quieto. Rapidamente saí do carro com intenção de saber um pouco mais sobre ele.

Aproximei-me de uma senhora que ali se encontrava; apresentei-me a ela dizendo meu nome e ela também disse seu nome (Alice). Expliquei-lhe o objetivo do trabalho e o interesse de trabalhar com a família do rapaz. Por coincidência, ela era umas das vizinhas que conhecia perfeitamente o menino e a família dele. Imediatamente ela se dispôs a me colocar em contacto com a família e me conduziu até a casa do rapaz.

Assim, fomos a casa dessa família que não era longe do lugar onde nos encontrávamos aproximadamente um quilômetro, mas seguimos de carro. Durante o percurso fui fazendo algumas perguntas sobre o rapaz e sua família. Dona Alice disse que ele se chamava Bernardo e que era maluco. Sobre a família, disse que eram pessoas muito simples e não falavam português. Porém, o que mais me chamou atenção foi saber que o rapaz ficava acorrentado, mas não me explicou o motivo e eu tampouco perguntei.

Perguntei se Dona Alice conhecia outras pessoas como Bernardo e ela respondeu que havia um rapaz que morava um pouco mais distante, mas que ele já tinha sido atendido e recebia apoio. Dona Alice não explicou detalhadamente, mas eu pude entender que se tratava de um apoio financeiro recebido da Ação Social. Por ela dizer isso, procurei esclarecer que meu objetivo não era atendê-lo, mas realizar uma pesquisa.

Como não falo Yao, Dona Alice se disponibilizou em me auxiliar na interpretação, se fosse necessário. Prontamente aceitei e ela seguiu me ajudando durante todo o tempo de contato com a família de Bernardo.

A seguir apresentarei as principais anotações que fiz nos dias em que estive com Bernardo e sua família. 


\subsection{Diários de campo}

\section{- $1^{\circ}$ dia 17 de Novembro}

Acompanhada por Dona Alice chegamos à casa da família do Bernardo, mas sem ele, pois o rapaz se recusou a nos acompanhar e continuou na rua.

A casa desta família é típica da zona rural, de fabrico precário, feito de barro (pau-a-pique) e cobertura de capim, sem energia elétrica e nem água canalizada. $\mathrm{O}$ banheiro fica na área externa e a construção é feita com estrutura de bambus e pau-apique forradas com capim; a latrina é feita com um buraco no chão. $O$ terreno, por sua vez, é cercado com bambus e capim onde estão situadas as duas palhotas (casas), tipo gêmeas.

Em uma das palhotas vivem as duas avós Amélia (70anos), materna, e Aurora (82), paterna, e Bernardo; na outra vivem a mãe, Dona Natalia (40) e os irmãos: Maria (22), Alberto (14), Antonio (11), Angelica (7anos) e Eurico (2). Maria tem um filho chamado Júlio, de dois anos, que vive com eles. O pai de Bernardo não mora com a família desde que Bernardo tinha um ano e seu paradeiro é incerto, mas seu tio Abdul (58 anos), irmão do pai, visita-os sem muita regularidade. Eles sãos únicos filhos de Dona Aurora. Dona Natalia é atualmente a única filha viva de Dona Amélia, pois seus dois irmãos já faleceram. Dona Natalia é separada de dois casamentos anteriores e é a chefe da família, tal como ocorre na maior parte das famílias da região.

Quando chegamos a casa desta família, encontramos as avós sentadas em cadeiras no quintal; a mãe de Bernardo estava amamentando Eurico e os irmãos brincavam dentro do terreno da casa.

Assim que nós entramos, as pessoas se aglomeraram para entender o que se estava a passar. Cumprimentamos e a mãe do Bernardo levantou-se e cedeu um banco para nos sentarmos.

Imediatamente Dona Alice explicou, em Yao, quem eu era e objetivo da minha ida naquela casa. A mãe do Bernardo disse que não tinha problema, segundo a interpretação da senhora Alice, que eles estavam disponíveis em ajudar. Durante a conversa toda, a fala da mãe do Bernardo foi em Yao . 
Nessa primeira conversa perguntei sobre a condição de Bernardo e a mãe contou que o filho ficava acorrentando, confirmando a informação de Dona Alice. Dona Natalia explicou que nós só o encontramos na rua porque ele havia fugido com medo de ser submetido a um tratamento tradicional feito pelo curandeiro. Não pude saber em detalhes como seria feito o tratamento, mas a mãe me contou que o curandeiro usaria uma galinha preta que se encontrava no quintal da casa no momento em que eu cheguei. Segundo Dona Natalia, o tratamento tinha como finalidade tirar o espírito incorporado do irmão gêmeo de Bernardo, falecido quando eram crianças. Segundo a tradição Yao, explicado pelo curandeiro, quando um dos irmãos gêmeos morre, o outro corre o risco de morte ou ter problemas de saúde se não for submetido a um tratamento tradicional.

Dona Natalia explicou que esta era a terceira vez que tentavam submeter Bernardo ao tratamento, mas tal como nas outras vezes, o filho ficou agitado e fugiu, sendo encontrado por nós na rua. A mãe disse que depois dessa fuga não tentaria novamente o tratamento, pois o irmão gêmeo falecido não estava permitindo que isso acontecesse.

Em um dado momento, as avós e os irmãos começaram a falar, talvez contando coisas sobre Bernardo, mas eu não entendi porque falavam em Yao e todos ao mesmo tempo, dificultando o trabalho da minha interprete.

$\mathrm{Na}$ conversa feita nesse dia soube também que a família passava mais tempo na machamba (roça) do que em Sanga-Sede, onde ficava a casa que eu visitei.

O trabalho da roça é todo realizado pela Dona Natalia com ajuda apenas de Maria, sua filha mais velha, mas todos os filhos a acompanham, inclusive Bernardo. Apenas as avós permanecem, pois o tempo estimado de caminhada até a machamba é de 12 horas.

Esta família não tem muitos recursos financeiros, e a base de sustento vem da machamba, onde cultivam milho, feijão, mandioca, batata doce, verduras e amendoim. Os produtos vindos da roça são guardados num celeiro e muitas das vezes alguns desses produtos são utilizados para a sementeira nas épocas subsequentes.

Todos os membros da família são analfabetos e muçulmanos, como a maioria da população da região. 
No final me despedi na promessa de voltar em outro dia. Antes de partir, mostrei a foto do Bernardo tirada quando eu o encontrei na parada da viagem de Mavago a Lichinga. Em língua Yao avó materna disse: meu deus, como é bonito, e logo em seguida pediram para tirar uma foto também. Atendi ao pedido da família tirei a foto. Achei essa família bastante calorosa e alegre.

A visita nesse dia teve a duração de 2 horas e meio aproximadamente.

\section{- $2^{\circ}$ dia - 24 de Novembro}

Neste dia, mas uma vez, contei com o apoia da Dona Alice, como já tinhas combinado desde o início.

Cheguei à casa da família às dez horas da manhã e encontrei a mãe, Dona Natalia lavando a roupa, as avós sentadas, os irmãos do Bernardo brincando, tal como no dia anterior, mas nesse dia Bernardo estava presente, parado, em pé, num dos lados da casa, da mesma forma como quando o encontrei pela primeira vez.

A idéia do trabalho nesse dia era observar apenas, atividade essa que ficou difícil de fazer porque ao invés de ser eu a observadora, eram eles que me observavam.

Tal como na primeira visita, eles ficaram aglomerados, olhando para mim, o que me causou certo constrangimento. Mesmo assim, comecei a conversar com Dona Natalia. Pedi a ela para me contar como foi à gravidez e parto do Bernardo. Ela respondeu que o parto foi normal e não teve problemas quando nasceram seus filhos gêmeos, mas um deles morreu aos seis meses e ela ficou triste.

Depois que o irmão morreu, Bernardo passou a chorar muito, 'fora do normal', conforme a mãe, e por isso o levou ao hospital. Após examinar o bebê, os médicos disseram que ele não tinha nenhum problema. Com o tempo o choro de Bernardo foi diminuindo e a preocupação da mãe passou. Contudo, por volta dos sete anos, a mãe voltou a ficar preocupada porque o filho não falava e gritava muito. Dessa vez, a mãe não levou o filho ao hospital e preferiu consultar o curandeiro. Foi nessa ocasião que lhe foi explicado que a criança estava possuída pelo espírito do irmão e tinha que ser 
submetido a um tratamento tradicional, o mesmo do qual Bernardo havia fugido no dia anterior.

Perguntei a mãe sobre o dia-a-dia de Bernardo. Dona Natalia contou que logo que ele acorda é tirado do quarto das avós e é acorrentado, nunca demonstrando resistência. O 'mata-bicho’ (café da manhã), geralmente resto do dia anterior, composto por 'chima' (polenta branca e dura) e um 'caril' (caldo de verdura, feijão ou peixe) é servido para Bernardo no local onde fica acorrentado.

Nesse local, embaixo de uma grande árvore, também há um buraco onde ele faz as necessidades como urinar e defecar. Segundo a mãe, foi o próprio Bernardo que fez o buraco embaixo da raiz da árvore. Assim como o café da manhã, as demais refeições também são levadas para esse local. Como permanece acorrentado durante o dia todo, Bernardo não participa de nenhuma atividade do cotidiano da casa. Embora a mãe tenha relatado que Bernardo fica acorrentado, em nenhum dia que eu estive ali vi o rapaz acorrentado.

Perguntei a mãe o motivo pelo qual ele fica acorrentado, visto que Bernardo é um rapaz que à primeira vista não aparenta ter qualquer tipo de deficiência. Somente com uma observação mais atenta é que se nota seu olhar fixo, sem pestanejar e quando falam com ele não responde, apenas sorri. A ausência de higiene também é notável devido ao cheiro forte e desagradável. Embora apresente esta aparência não observei nenhum comportamento que justificasse sua contenção física. Todavia, Dona Natalia explica que quando Bernardo fica solto invade a casa dos vizinhos e pega seus pertences.

Neste dia, enquanto eu conversava com a mãe, os irmãos mais novos do Bernardo o chamavam pelo nome:"Bernardo, Bernardo, Bernardo"'- $e$ ele respondia com um olhar sorridente.

Tal como no primeiro dia, em um dado momento as avós e os irmãos começaram a falar todos ao mesmo tempo, mas não consegui entender porque novamente a interprete não deu conta de interpretar. 
A rotina desta família, é muito tranquila, passam maior tempo sentados conversando e sem muita atividade, por isso que a ideia de fazer observação não funcionou muito, eu tinha que estar sempre a dialogar.

A crença de que, o rapaz está possuído, pelo espírito do irmão, é muito forte, porque na conversa com mãe em nenhum momento ela falou do hospital, apenas do curandeiro.

Em conversa com esta família, quando se fala do Bernardo, não é de lamentação e nem desanimo, mas também não foi demonstrado nenhum movimento no que diz respeito ao investimento deste ou uma preocupação com o seu futuro.

Esta atividade teve duração de uma hora e meia aproximadamente.

\section{- $3^{\circ}$ dia - 26 de Novembro}

Esta foi a primeira vez que eu fui de um transporte público e eu não tinha noção da dificuldade de transporte. Na companhia do meu primo, ficamos no ponto de ônibus em torno de três horas, com alegação de que o transporte só poderia sair porque assim que estivesse cheio. Portanto das 9 às 12 horas e para chegar a Sanga levamos duas horas partindo de Lichinga e chegamos quando eram 14 horas. Era tarde como o transporte era escasso, calculamos, em fazer o trabalho e retornar com o mesmo transporte que poderia ser o último do dia.

Antes passamos pela casa da senhora Alice, que teria nos esperado a manhã toda, ainda assim contamos com o apoio desta na interpretação.

Assim fomos à casa da família e chegamos pouco antes da refeição. A mãe estava preparando o almoço e as avós, como sempre, sentadas em seus banquinhos. Dona Amélia, a avó materna, convidou-me para sentar ao lado dela, como uma demonstração de carinho na minha percepção.

O almoço foi logo servido e todos se sentaram no chão, ao redor de um único prato do qual todos comeriam, menos Bernardo, servido em um prato separado, mas sentando-se próximo dos demais. Assim que a comida foi servida, Dona Natalia 
convidou a mim e ao meu primo para comermos juntos, mas agradecemos e não comemos porque notamos que a comida era pouca. Nesse dia comeram chima (polenta) e feijão. Bernardo enquanto comia parava, olhava para mim, sorria e continuava comendo.

Depois da refeição, eu perguntei a Dona Natalia porque Bernardo estava solto se havia me contado que sempre ficava acorrentado. A mãe respondeu: eu sabia que mama vinha por isso que não acorrentei, segundo tradução de Dona Alice. Embora tenha falado em Yao, consegui compreender quando Dona Natalia disse mama, que significa mãe. Em Moçambique chamar uma mulher de mãe é sinal de muito respeito.

Dona Natalia contou que Bernardo gritou muito no dia anterior. Perguntei o motivo e ela disse que era por causa do espírito, que ele estava possuído.

A mãe contou também que Bernardo não foi submetido aos ritos de iniciação, uma cerimônia bastante importante na vida dos jovens desta região, quando é feita a circuncisão. Bernardo não participou por causa da doença ${ }^{22}$, pois a mãe temia que ele ficasse mexendo na ferida e por isso nunca sarasse.

Segundo Dona Natalia, a comunidade tem um bom relacionamento com Bernardo, principalmente quando ele não faz estragos. Nunca foi espancado, apenas ameaças de repreensão por ele pegar pertences dos vizinhos sem autorização e perdelos, repetindo o que havia me contado no dia anterior. Já existiram casos em que os vizinhos vieram reclamar e cobrar da família os objetos subtraídos. Por esse motivo a mãe relatou que o acorrenta, visto que ela nem sempre consegue pagar esses pertences por falta de recursos.

Apesar de eu nunca ter visto o Bernardo acorrentado, percebi que, desde primeira vez que eu entrei naquela casa ele nunca mais foi acorrentado, e não invadiu a casa dos vizinhos, mesmo que segundo a mãe seja por saber que eu iria.

Esta família não conta com apoio do governo para atender outras necessidades, contam com a boa vontade dos vizinhos, ajudando-a doando roupas e alimentos eventualmente.

\footnotetext{
${ }^{22}$ Não sabemos se a mãe usou o termo 'doença', mas assim foi traduzido por Dona Alice.
} 
Como no dia anterior, os irmãos mais novos chamavam-no pelo nome “Bernardo!" e ele respondia sorrindo de forma meiga. Pude notar uma relação afetuosa entre os irmãos e Bernardo, porém observei que a interação se limitava a isso, sem outro tipo de contato, pelo menos nos momentos em que eu lá estive.

Pude notar também que a minha presença mudou a rotina da família e de Bernardo, visto que ele passou a ficar maior tempo solto e mais próximo da família, realizando inclusive a refeição mais próximo dos demais. Conversando com a mãe, percebi que ela falava do filho olhando-o com um sorriso comovente.

Pelo que pude entender, a mãe acorrenta Bernardo para evitar atritos com a vizinhança, pois quando estão na machamba (roça), onde não tem tanta gente, ele fica solto o tempo todo.

Nesse dia permaneci cerca de uma hora e meia com a família. Próximo do final da tarde, despedi-me com a promessa de voltar na próxima semana.

\section{- $4^{\circ}$ dia 29 de Novembro}

Neste dia, fui novamente de um transporte público na companhia do meu primo; chegamos a Sanga quando eram onze horas. A senhora Alice já se encontrava a minha espera, em seguida nos dirigimos à casa da família. Quando entramos, teve aquele aglomerado habitual, mas desta vez durou pouco tempo. Apenas continuaram sentadas as avós e a mãe.

O Bernardo nessa altura se encontrava parado num dos cantos da casa. Assim que ele me viu, sorriu e veio sentar-se do meu lado, olhava para mim sorrindo, ai eu tentei puxar conversa para ver a reação dele, o que conseguia arrancar dele era mesmo um sorriso que até contagiava a todos que ali se encontravam isso é, a mim, a mãe, a avós, a senhora Alice e ao meu primo.

Saudei a família e logo em seguida a mãe disse que volatriam à machamba onde passavam maior tempo. 
Percebi que eles já sentiam mais a vontade na minha presença e eu também com eles. Mesmo assim não foi fácil. Porque quando eu ficava calada, a sensação era igual quando se está num grupo onde as pessoas estão conversando e de repente ficam calados, ficando apenas troca de olhares; em vários momentos me vi sem graça.

A mãe do Bernardo levantou-se colocou o filho Eurico no colo, sentou-se ao redor da fogueira e começou a cozinhar. Fez chima com feijão que serviu logo em seguida. Tal como da última vez, todos se sentaram para comer no mesmo prato, menos o Bernardo. Algo que me chamou atenção.

Depois da refeição, continuei conversando, e procurei saber como é que era na época das festividades do Nyago se o Bernardo participava também.

Segundo a mãe o período de Nyago (ritos de iniciação) em que as pessoas se unem para as festividades, e todos entram nas casas uns dos outros a família do Bernardo também se fazia presente menos o Bernardo.

Segundo dona Natalia, ele não vai porque não seria permitido sob alegação de que não passou do Nyago, requisito fundamental para conviver com os outros que tenham passado.

Uma coisa que também pude perceber é que nesta comunidade, não é comum se encontrar pessoas falando uma das outras, podem até existir, mas não da perceber porque os terrenos são vedados de capim, e muito altos, não dá para perceber o que acontece dentro do quintal do vizinho.

Este dia foi menos produtivo, porque no meu ponto de vista as atividades estavam bastante repetitivas. Durou duas horas.

\section{- Última visita dia 04 de Dezembro}

Neste dia, retomei algumas questões anteriormente postas para a família e por mim observadas com a intenção de checar o entendimento que tive durante esses dias e também fazer uma síntese.

Cheguei junto da Dona Alice quando eram dez horas da manhã. O ambiente que eu encontrei não foi muito diferente dos outros dias, só que nesse dia os irmãos estavam 
brincando fora do quintal com outros amigos. O Bernardo estava sentando sozinho debaixo do celeiro, dentro do terreno da família. A roupa que o Bernardo trazia era a mesma do primeiro dia que eu o encontrei na rua e mesma com a qual ele se apresentou em todas às vezes.

O Bernardo é um rapaz que está insento de quase todas as atividades, seja na família ou na comunidade; não tem amigos, passa maior tempo isolado. Um rapaz na idade do Bernardo, seja nos Yao ou em outra etnia, ou em qualquer região que não fosse Sanga, estaria envolvido em muitas atividades como: fazer negócio, trabalhar em machambas, teria amigos, estaria a pensar em se casar, participaria da construção da casa.

Percebe-se também que nesta comunidade não existe um órgão competente em funcionamento no sentido de proteger crianças na situação do Bernardo.

A crença de que este filho está possuído pelo espírito do irmão é muito patente. Tanto é que a procura pela cura foi sempre no curandeiro ou no tratamento tradicional.

Esta atividade de observação foi muito difícil porque praticamente eles passavam a observar-me também. Da forma como a família me olhava, era como se eles estivessem admirados por eu estar ali naquele momento, em vários momentos fiquei sem saber o que fazer.

Esta mãe é uma mulher forte, que tenta manter a sua família como ela pode. A mãe e todos os filhos passam maior tempo na machamba principalmente na época da sementeira e da colheita. Não tem apoio do Governo e para responderem com as outras necessidades como vestuário, por exemplo, contam com a bondade dos vizinhos.

A atividade deste dia teve duração de duas horas e meia aproximadamente. 


\subsection{Síntese das entrevistas aos agentes:}

\section{a) Ação social:}

Segundo a ação social os casos de deficiência mental são poucos. Os casos comuns são: deficiência física, auditiva e visual. Os casos chegam a esta instituição, a partir das reportagens da própria comunidade.

Entretanto nem todos os casos recebem apoio da ação social somente os casos considerados vulneráveis. São considerados vulneráveis segundo ele aqueles não têm capacidade econômica para atender situações imediatas.

Para se chegar a esta conclusão de que são vulneráveis, faz-se um histórico social, e apoio é feito de acordo com as suas necessidades. Por exemplo: se for um deficiente físico que tenha dificuldade de se locomover então a sua necessidade principal e de uma carinha roda.

Alguns casos são encaminhados ao INAS (instituto Nacional de Ação Social) assim acontece quando a ação social não consegue responder a demanda. Portanto eles se beneficiam de um subsídio básico mensal de 130 meticais $^{23}$ equivalente a 15 reais, este valor vai aumentando de acordo ao número do agregado familiar da pessoa deficiente.

Essas pessoas continuam morando no seu meio familiar, contanto com uma assistência comunitária.

Existem casos de rejeição pela família, sob alegação de que é azar, quando assim acontece a é feito um trabalho de conscientização pela ação social no sentido de fazer entender a família que este indivíduo precisa deles.

Segundo o entrevistado, existem outros serviços como recursos de educação inclusiva, que esta especificamente preparada para pessoas com deficiência auditiva, visual e física.

\footnotetext{
${ }^{23}$ Moeda Moçambicana
} 


\section{b) Parteira:}

A entrevistada trabalha há 12 anos na saúde. Ela diz que o trabalho é bom porque ela gosta do que faz sempre que ela faz um parto é motivo de alegria.

Semanalmente tem feito no mínimo oito partos. Já tiveram partos em que a criança teria nascido deficiente, como também partos complicados. Nas vezes em que os partos foram complicados, na maioria das vezes, a família recorreu ao curandeiro, forma de encontrar uma saída perante aquela dificuldade.

Quando assim acontece eles não impedem, porque reconhecem a importância que os curandeiros tem para algumas famílias. Já existiram casos em que a família sentiu-se obrigada a abandonar a criança por considerar uma aberração. Em muitos casos a reação dos pais é sempre de rejeição até ao último momento.

Segundo ela ainda teve um caso que mais the marcou que não consegue esquecer: de uma mulher que teve seu primeiro filho com deficiência, cujo aspecto físico dele era completamente desfigurado a partir da boca, olhos, braços e pernas. A mãe aceitou a criança, mas não tinha vontade de amamentar. Segundo o curandeiro, tinha a ver com a sogra, porque ela estava descontente porque o filho casou-se com ela.

\section{c) Curandeiro:}

Segundo o entrevistado começou o trabalho com sentimentos de feitiço na família, dormia nas noites e acordava com crianças no mato. Andou quilometro de distância a procura de curandeiro. O primeiro caso que ele atendeu, foi em Maputo capital de Moçambique.

O segredo do curandeiro e ter machamba (roça) para não ter que depender dos doentes e ser oportunista. Já foi convidado a acompanhar um parto, que tinha ver com coisas feita. Onde a criança nasceu com defeito na perna. Assistiu esse doente junto aos médicos. Segundo ele todos os casos que ele já tratou teve solução.

Ainda segundo ele para que os casos tenham sucesso, faz manobra para conseguir solução. Disse ainda este curandeiro Yao, essas doenças têm sempre a ver 
com questões familiares assim como de deus também. $\mathrm{O}$ tratamento inclui a criança e mãe.

\section{d) Líder tradicional:}

Segundo o entrevistado os Yao começaram com o Régulo Mataka. O nome Yao vem do monte Yao. O Régulo Mataka é quem fazia troca de pessoas de um lado para outro. Jaua é como são denominadas as pessoas da etnia Yao que nascem no monte Yao. A história deste povo vem da divisão dos povos macuas e Nyanjas.

O nascimento de uma criança nos Yaos e uma alegria, o jovem e ensinado a respeitar os mais velhos. Portanto o nascimento de uma criança e comemorado do com alegria é motivo de festa.

Uma criança que passa pelos ritos de iniciação tem diferença com a outra que não tenha passado. É mas respeitosa, tem um tratamento de pessoas adultas. Os que não passam são mal educados, não respeitam os hábitos da cultura.

Quando nasce uma criança com deficiência não é comemorado com festas, fazse uma promessa (naciri), na perspectiva de ver ela curada, quando isso não acontece, não tem festa é motivo sim de tristeza.A educação tradicional(ritos de iniciação) é feita a partir dos 12 anos.

Uma criança deficiente pode não ser educada como outras crianças dependendo do tipo de deficiência. Pode ser submetida aos ritos dependendo do tipo de deficiência. Pode ser submetida aos ritos da mesma forma que as outras crianças, só que existem que certas crianças com deficiência não conseguem fazer. 


\subsection{Discussão dos resultados:}

A partir dos resultados anteriormente apresentados, foram propostos alguns temas/eixos para aprofundamento da discussão e análise.

\section{a) Participação/exclusão de Bernardo na rotina da família e na comunidade}

A família da dona Natalia, mãe do Bernardo e chefe da família, é constituída por dez pessoas: a mãe, duas avós, cinco filhos e um sobrinho.

Esta família tem poucos recursos financeiros e a base de sustento vem da machamba, não contam com o apoio do governo porque segundo a ação social o caso do Bernardo não é prioridade. Todos os membros da família são analfabetos e muçulmanos, como a maioria da população da região.

A rotina desta família é muito tranquila, passam maior tempo sentados, conversando e sem muita atividade. As avós ficam mais tempo sentadas e dona Natalia é quem cuida da refeição e dos filhos menores. De tempos em tempos vão à machamba (roça).

Tendo como referência esse contexto, é difícil dizer em que medida Bernardo participa ou não das atividades, visto que a maior parte das tarefas é realizada apenas pela mãe com alguma ajuda da filha mais velha; nesse sentido, a participação de Bernardo não difere muito de seus irmãos menores. Por outro lado, não seria correto afirmar que ele participa, tendo em vista que ele permanece a maior parte do tempo acorrentado para não entrar na casa dos vizinhos e pegar seus pertences, conforme relato da mãe. Mesmo quando não esteve acorrentado, situação observada nos dias da visita, Bernardo manteve-se à parte, parado, de pé em um canto do terreno da casa.

Se for considerado apenas a ajuda nas tarefas da casa, que não são muitas, a participação de Bernardo não difere da demonstrada por seus irmãos, porém ao se observar o cuidado com a higiene a diferença será notável. Diferentemente de seus irmãos, Bernardo não apresentou nenhum cuidado de higiene, permanecendo com a mesma roupa desde o dia em que foi encontrado pela pesquisadora, com um odor bastante forte. A ausência de cuidados pode ser explicada pelo fato de Bernardo já ser um rapaz e não haver na casa nenhum adulto do sexo masculino para orientá-lo e 
supervisioná-lo, talvez sendo constrangedor para as avós, a mãe e a irmã mais velha realizar essa tarefa. Mas isso é apenas uma suposição.

Mesmo diante de sua condição, não foram observadas atitudes de discriminação, recriminação ou punição em relação a Bernardo. Vale ressaltar que o acorrentamento do jovem ocorre devido às constantes reclamações dos vizinhos quando eles percebem seus pertences subtraídos e sem a mãe poder ressarci-los por falta de condições financeiras. Nesse sentido, o acorrentamento não tem como finalidade punir Bernardo, mas evitar problemas com os vizinhos, tanto que quando estão na machamba, o rapaz permanece solto.

De modo geral, foram observadas relações bastante afetuosas entre os membros da família e destes com Bernardo e também com a pesquisadora, como na ocasião em que foi convidada a se sentar perto das avós e quando foi convidada a almoçar. Os irmãos diversas vezes chamaram Bernardo pelo nome quando este se encontrava aparentemente isolado e este respondia ao chamado com um sorriso, visto que não se expressa verbalmente. A qualidade da interação é limitada, mas afetuosa, não sendo observada nenhuma atitude de indiferença, depreciação ou humilhação de Bernardo, pelo contrário, pode se inferir que há por parte dos irmãos a intenção de se aproximarem de Bernardo. Segundo a mãe, quando Bernardo está acorrentado, os irmãos costumam dividir com ele o que estão comendo.

A observação da relação dos irmãos com Bernardo remete à pesquisa de Messa e Fiamenghi (2010) que ressaltam a importância da interação entre os irmãos como estímulo ao desenvolvimento do irmão com deficiência. No estudo, os autores citam a pesquisa realizada por Naylor \& Prescott que apontam a importância dos grupos de apoio na preparação dos irmãos. Essa pesquisa mostrou que os irmãos que participaram desses grupos de apoio, ganharam consciência da necessidade de ter mais paciência com o irmão deficiente. Considerando a referida pesquisa, seria fundamental a orientação e assistência aos irmãos de Bernardo, assim como à mãe de Bernardo.

As avós e a mãe também manifestaram afeto por Bernardo, seja nos comentários, como aquele da avó ao ver a foto do neto, como pelos olhares dirigidos ao rapaz, mesmo quando este se encontrava distante. 
Embora a maior parte das observações tenham indicado atitudes de aproximação e inclusão por parte da família, pelo menos duas situações pareceram indicar, à primeira vista, alguma forma de discriminação. Uma delas é o fato de Bernardo ser o único filho que dorme na casa das avós. Algumas conjecturas podem ser levantadas, como a necessidade de separá-lo dos demais devido a uma possível manifestação da sexualidade, porém não há nenhum dado que possa confirmar isso. Outra situação, que de certa forma é ambígua, foi no momento da refeição. Bernardo é chamado para ficar perto dos demais, porém foi o único a comer no prato separado. Todavia, aparentemente essa situação não mostrou ser problemática para nenhum deles.

Saindo da esfera familiar, foi dito pela mãe que Bernardo tem que permanecer acorrentado por entrar na casa dos vizinhos, provocando atrito com os mesmos. Todavia, a mãe não relatou nenhum episódio de agressão ou ameaça a Bernardo. Isto não significa, no entanto, que tais episódios não tenham ocorrido.

Em relação às tradições, Bernardo não foi submetido aos ritos de iniciação, uma cerimônia bastante importante na vida dos jovens desta região, quando é feita a circuncisão (Nyago). Esse fato impede que Bernardo participe das festividades da comunidade, segundo a tradição Yao. Embora seja uma forma de segregação, é interessante notar que isso ocorre não pelo fato de Bernardo ser deficiente ou doente, termo usado pela mãe, segundo tradução da interprete. Ou seja, pelo que se pode entender, mesmo sendo doente, se Bernardo tivesse passado pelo rito de iniciação, poderia tal como os demais participar das festividades.

Outro aspecto interessante é que a proibição não é extensiva à família. Durante o período de permanência no campo não foram notadas nenhuma forma de discriminação da família pelo fato de ter um filho com deficiência. Desse modo, pode-se considerar que se há algum estigma, aparentemente este não é extensivo à família.

\section{b) Como a mãe entende a condição do filho;}

Segundo mãe a gravidez e o parto dos gêmeos foi normal. A mulher grávida nos Yao deve seguir algumas regras, impostas pela tradição. O não cumprimento destas tem consequências drásticas. (AMARAL 1990, P.58). 
No relato a mãe contou que não seguiu estas regras da tradição, porém não se referiu a não observância desses rituais como causa da morte do outro gêmeo e deficiência do Bernardo.

A origem da doença tem uma explicação tradicional, isto porque os médicos não conseguiram identificar algum problema de saúde no Bernardo. Segundo a mãe o seu filho está possuído pelo espírito do outro filho que teria falecido. A busca pelo tratamento foi sempre no curandeiro e não no hospital.

O diagnóstico do curandeiro foi fundamental para esta família, uma vez que os médicos não conseguiram detectar algum problema nesse rapaz, a prova disso é durante a pesquisa de campo, não foi mencionado em nenhum momento que se pretendia procurar a opinião de outro médico.

A resposta de um curandeiro, que muitas das vezes é adivinho ao mesmo tempo, é importante na vida dessa comunidade, porque carrega com ele o poder de se "comunicar com o mundo invisível e recorre á sabedoria dos antepassados e as forças da natureza". (WEGHER,1997.P.53).

O objetivo do tratamento é tirar o espírito do irmão gêmeo morto que se incorporou no rapaz. Esta crença é muito forte, um pouco por todo Moçambique. Ela é fundamentada da seguinte forma: se um dos gêmeos perde a vida, o outro também corre risco de perder a vida, isto se não for submetido a um tratamento tradicional. Seja dentro da cidade ou em zonas rurais a crença de que isso possa ocorrer é muito forte e várias pessoas saem em busca do tratamento no curandeiro isto porque cientificamente não tem nenhuma explicação.

Esta crença é tão forte, tanto é que quando o Bernardo grita nos dias em que ele está agitado, Dona Natalia diz que é por causa do espírito que incorporou nele, ou seja, está possuído.

A rejeição do tratamento por parte do rapaz fortificou ainda o argumento de que estava possuído. Segundo a mãe depois dessa fuga não tentaria novamente o tratamento, pois o irmão gêmeo falecido não estava permitindo que isso acontecesse.

Entender-se-ia que de certa forma, sente-se a presença do outro gêmeo que não conseguiu sobreviver. 
Portanto a crença pelo curandeiro neste caso foi sem dúvida um grande ponto de partida, que de certa forma guiou a relação desta família com o menino uma vez que, cientificamente não teve uma explicação. O que muitas vezes a ciência não consegue explicar, a magia explica e chega até resolver. O caso do Bernardo infelizmente não teve solução.

O diagnóstico dado pelos agentes de saúde é importante e permitirá a criação de um vínculo com a família isso passaria necessariamente pelo esclarecimento e informações ofertadas à linguagem utilizada, ao tipo de atenção dispensada, a maneira como a equipe de saúde acolhe a família e ao convívio entre eles. (MILBRATH, et.al. 2011).

Por outro lado, o hospital nessa região não oferece estrutura suficiente para dar suporte a famílias como da Dona Natalia. Portanto não dá para responsabilizar aos agentes de saúde, o que não nos impede de refletir sobre elas.

Ainda que o diagnóstico médico seja importante, estes não podem ficar alheios às influências culturais da sociedade onde se encontram. Portanto é necessário conciliar essas tradições com as questões científicas. (MARTINS, et. al., 2012).

Portanto esta explicação sobre a doença do Bernardo é também compartilhada pela maior parte das famílias Moçambicanas, como tenho vivenciado. Os serviços de saúde, apesar de procurarem uma explicação a partir da ciência, acompanham as práticas da tradição, quando se sentem impotentes diante de certas deficiências, reconhecendo desta forma a importância do curandeiro no tratamento da doença, como aponta à parteira. Esta posição da parteira reforça a versão do curandeiro que, em alguns momentos precisou unir-se ao médico para cuidar de um determinado paciente.

Segundo o Régulo (Líder tradicional), o nascimento de uma criança deficiente não é comemorado com festas como tem acontecido quando se trata de uma criança sem deficiência. Apenas faz-se uma promessa, na perspectiva de ver ela curada. Quando isso não acontece é motivo tristeza.

Se nos basearmos apenas pela visão do mundo, no diz respeito a ciência e superstição, poderíamos considerar a família do Bernardo como atrasados desqualificando todos os outros fatores igualmente importantes. Isso pode ficar mais 
claro a partir das falas dos agentes onde trazem vários pontos que possam ajudar a pensar a situação do Bernardo.

Os agentes da saúde e da ação social mostraram que em vários momentos sentiram-se impotentes em resolver situações que são da sua responsabilidade. $\mathrm{Na}$ versão do Líder tradicional, uma criança com deficiência dependendo do tipo deficiência pode ser submetida aos ritos de iniciação onde são educados de acordo as suas tradições tal como os outros, se o seu estado permitir. Segundo o curandeiro o tratamento dá sempre certo, apenas a mãe e criança são submetidas ao ritual.

Há uma crença de que enquanto estiver atormentada pelo espírito sua condição não poderá ser mudada, isso ficou claro que de certa forma pode não ocorrer uma vez o Bernardo rejeita o tratamento.

Segundo a literatura o momento da noticia para uma família de que o filho nasceu com deficiência, muitas vezes é vivenciado por sentimentos contraditórios como frustração, desanimo, culpa, dentre outros.

Isso não foi observado com esta mãe pelo seu relato pois, da parte dos médicos não foi identificado nenhum problema no Bernardo.

Ela viu no curandeiro, a possibilidade de uma resposta pelo que estava acontecendo com seu filho, aonde veio o diagnóstico que ele estava possuído. A relação desta mãe com a doença do filho centrou-se no tratamento tradicional para expulsar os espíritos que o amedrontava.

Uma vez que sempre que ela recorresse ao tratamento, era visível segunda ela uma agitação por parte do filho, o que fortificou essa ideia de incorporação do espírito de outro irmão, ela optou pela desistência no tratamento. Segundo dona Natalia, a condição do Bernardo é irreversível.

A preocupação dela no que se refere a este filho com deficiência é centrada em outros aspectos, como alimentação, a relação com os vizinhos por esse fato ela o acorrenta. 


\section{c) Relação pesquisadora-família-Bernardo:}

Nos primeiros dias de campo, era muito constrangedor a forma como as pessoas olhavam para mim. Isso tem muito a ver com a forma como o pesquisador entra no campo e como ele é olhado. Segundo a mãe, nunca ninguém tinha se interessado pela vida do filho. Nunca contaram com apoio de nenhum órgão social e do governo.

A relação com a família dentro campo, foi mudando com tempo. No início, as pessoas aglomeravam-se e me olhavam com um olhar tímido, às vezes eu me sentia constrangida. Foi mudando com tempo, aglomeravam-se, mas passou a durar pouco tempo em relação ao início. A forma como eu era chama pela dona Natalia, é sinal de muito respeito naquela zona, $\operatorname{Mama}^{24}$.

Pude perceber que essa mudança se estendeu a Bernardo, pois no início olhava para mim, sem dizer nada, a partir do terceiro dia, ele não só olhava para mim e sorria, mas também do meu lado era onde preferia se sentar.

A minha percepção antes de ir ao campo era totalmente diferente do que encontrei; a ideia era viver um tempo com a família para obter mais dados. Apesar de eu ter sido bem recebida não me senti á vontade para sugerir a família que eu dormisse na sua casa, pelo motivo de não muitos recursos. Ao invés destes se sentirem à vontade com a minha presença demandaria um movimento e uma quebra de rotina na sua dinâmica, criando um constrangimento até certo ponto, diminuindo o pouco espaço compartilhado por estes assim como sua alimentação.

Uma visita á família como a do Bernardo em Moçambique, de imediato, suscita uma reorganização na sua dinâmica. Ou por outra a preocupação é maior no sentido agradar a todo custo. Este um aspecto que pode parecer simples pensando num pesquisador, mas no momento fez muito sentido para além de outros fatores, que de alguma forma fizeram com que eu repensasse que fizeram o meu campo. Foi sem dúvida uma grande vivência e aprendizado que poderei usar nos próximos trabalhos.

\footnotetext{
${ }^{24}$ É uma forma carinhosa e respeitosa de chamar as mulheres seja na zona rural assim como na cidade.
} 


\section{Considerações finais:}

A pesquisa teve por objetivo investigar a relação de uma família do grupo étnico-linguístico Yao com um filho com deficiência.

Esta família com quem eu tive contato durante alguns dias é semelhante a muitas outras famílias pobres de Moçambique, que vive com poucos recursos, que não contam com apoio do governo para atender suas necessidades básicas e sem acesso aos serviços de saúde. É nesse contexto que dona Natalia cuida de seus seis filhos, sendo um deles um jovem com deficiência intelectual, um neto, sua mãe e sua sogra.

A participação do filho com deficiência na dinâmica da família e da comunidade foi um aspecto previamente proposto na pesquisa, podendo ser considerado incoerente com a perspectiva metodológica inspirada na pesquisa de tipo etnográfica. Não é possível ter claro o quanto essa questão orientou ou não a coleta dos dados. De toda forma, a análise dos dados coletados por meio da observação e participação do cotidiano da família ofereceu algumas pistas para compreender a relação estabelecida entre os membros da família e o jovem com deficiência.

Em síntese, pode-se notar relações afetuosas entre os membros da família, incluindo-se aí o jovem Bernardo. Em alguns aspectos ele recebe tratamento diferenciado: fica acorrentado, dorme com as avós e não come do mesmo prato dos demais. Todavia, não se pode afirmar que ele é totalmente segregado, mesmo quando se encontra acorrentado, pois os irmãos sempre buscam alguma forma de contato e Bernardo responde. Há que se considerar ainda que o acorrentamento ocorre como uma solução perante a reclamação dos vizinhos quando Bernardo invade suas casas. Nesse sentido, ainda que Bernardo receba um tratamento diferenciado em alguns aspectos, em vários momentos foram observadas atitudes de aproximação dos familiares, seja chamando seu nome, por uma expressão de afeto ou mesmo com o olhar que foi correspondido com o sorriso do jovem. Outro aspecto que pode ser considerado significativo na interação entre a família e Bernardo foi a ausência de manifestações de agressão verbal ou física, situações de humilhação deliberada ou atitudes de indiferença por parte dos membros da família. 
Em relação à mãe, não foi possível observar manifestações descritas na literatura especializada em relação à deficiência como: sentimento de culpa, superproteção, rejeição ou mesmo ambivalência de sentimentos. A partir das observações e conversas com a mãe não é possível afirmar em que medida dona Natalia demonstra descrédito em relação às capacidades do filho, pois segundo seu entendimento, a condição é explicada por uma doença causada pelo espírito do irmão gêmeo falecido. Ou seja, a doença não é uma consequência das condições ou limitações do filho, mas decorrente de uma causa que lhe é externa. Assim, avaliar Bernardo como capaz ou incapaz fica fora de questão, pois sua condição não depende de seus esforços ou da família. Pelo que se pode entender, quaisquer ações voltadas para melhorar sua condição, inclusive o tratamento tradicional realizado pelo curandeiro, parecem não ter efeito devido a interferência do espírito do irmão falecido. Tal atitude pode ser entendida como supersticiosa, fatalista e conformista se compreendida fora do contexto das tradições culturais dos Yao.

O aprendizado obtido na experiência de campo, no breve contato com a família, propiciou uma reflexão a respeito da importância do diálogo entre os diferentes saberes, no caso, o saber científico e o saber tradicional da cultura Yao. Deixar de lado os julgamentos prévios no contato com a família foi um grande desafio proporcionado pela pesquisa. Foi também desafiador ter que estar atenta não somente às relações familiares como também observar a minha relação com a família.

Além dos aspectos positivos proporcionados pela pesquisa penso ser necessário relatar também as dificuldades do processo. Em primeiro lugar, a dificuldade para encontrar uma família com um filho com deficiência, mesmo com a ajuda do representante do Conselho Municipal. A dificuldade de comunicação com a família em função da língua também foi bastante significativa, mas nesse aspecto o auxilio prestado por uma moradora da comunidade foi fundamental. Além dessas dificuldades, a limitação quanto à permanência no campo também foi significativa, implicando diretamente na coleta de dados.

A avaliação do trabalho aponta para alguns aspectos que poderiam ser aprimorados como a técnica de observação e registro que poderia contribuir para uma 
descrição etnográfica mais detalhada. Aprofundar a compreensão da dinâmica familiar, assim como compreender melhor a relação da família com a comunidade.

Esta pesquisa se encerra apontando a necessidade de se realizar mais estudos para se conhecer os significados da deficiência nos diversos grupos étnico-linguísticos de Moçambique e avaliar mais precisamente as condições necessárias para se promover uma melhor qualidade de vida das pessoas com deficiência e da população em geral 


\section{REFERÊNCIAS BIBLIOGRAFICAS}

ADORNO T. W. \& HORKHEIMER M. Dialetica do esclarecemento: fragmentos filosóficos , Rio de Janeiro,Jorge Zahar, 1985.

AMARAL, L. A. Conhecendo a Deficiência em companhia de Hércules: ROBE EDITORIAL, 1995.

AMARAL, M. G. O povo yao: subsídios para o estudo de um povo do noroeste de Moçambique, Lisboa, 1990.

AMIDE, J. B. "Wayao'we" no conhecido Niassa, Diname, 2008.

ANDRÉ, M. E. D. A. Etnografia da Prática Escolar: 9a edição, São Paulo: Papirus, 1995.

AZEVEDO,G. R. de \& SANTOS,V. L. C. G. (Handicapped) Caregiver: the social representations of family members about the caregiving. Ver.Latino-Am. Enfermagem, Outubro, Vol.1.14, P. 770-780, 2006.

BAPTISTA, S. M. \& FRANÇA, R. M. A família de pessoas com deficiência $\begin{array}{llllll}\text { desafios } & \text { e } & \text { superação, } & \text { Maranhão, } & \text { nr. } & 10\end{array}$ $\leq$ ww.apaenet.org.br/.../familia pessoas deficienci...> Acesso: 28 de Março. 2013.

BARBOSA, M. A. M. at. al. Cuidado centrado na família no contexto da criança com deficiência e sua família: uma análise reflexiva. Florianópolis, enfermagem, jan/mar. Vol.21, 2012.

BASTOS, O. M. \& SUELY, F. Sexualidade e deficiência intelectual: narrativas de pais adolescentes, Physis, Vol.22, nr. 3, p. 1031-1046, 2012.

BATISTA, S. M. \& FRANCA, R. M. Família de pessoas com deficiência: desafios e superação, Revista de divulgação técnico-científico do ICPG, Vol.3, nr.10,Janeiro/Junho,2007.

BOGDAN, R.C; BIKLEN, S.K. Investigação qualitativa em Educação. Porto: Porto Editora, 1999.

Boletim da República de Moçambique: $1^{\text {a }}$ serie. Nr. 23, supl, de 10 de junho de 1997, 
BRASIL. Constituição da República Federal do brasil. 1988. <http://www.planalto.gov.br/ccivil_03/constituicao/constitui\% C3\% A7ao.htm> Acesso: 20 de Set. 2012

BRASIL. Secretária Nacional da Promoção dos Direitos da Pessoa com deficiência<http://www.pessoacomdeficiencia.gov.br/app/legislacao-0>Acesso em: 21 Set. 2012.

BRUNHARA, F. \& PETEAN, E. B. L. Mães e filhos especiais: reações, sentimentos e explicações à deficiência da criança. Ribeirão Preto, Paidéia, Junho, Vol. 1.9, P. 3140, 1999.

CASTRO, S. S. Et. Al. Acessibilidade aos serviços de saúde por pessoas com deficiência, São Paulo, Outubro Vol. 1, 2011.

CHACON, M. C. M, Aspectos relacionados, familiares sociais da relação pai-filho com deficiência física, Rev. bras. educ. espec. Vol.17 nr.3 Marília, Set/Dec. 2011.

CHAMBAL, L. A. "Escolarização dos alunos com deficiência em Moçambique: Um Estudo Sobre a Implementação e os Resultados das Políticas da Inclusão Escolar". Dissertação de Mestrado apresentada no Programa de Pós-Graduação em Educação da PUC, São Paulo, 2007.

CIPIRE, F. Educação tradicional em Moçambique, EMIDIL, 1992.

Conselho de Ministros-Resolucao nr. 12/97 de 10 junho.

CROCHÍK J. L. Preconceito Individuo e Cultura, $3^{\text {a }}$.ed. São Paulo, casa do psicólogo 2006.

DISSEN, M. A. \& SILVA . N. L. Deficiência Mental e Família: Implicações para o Desenvolvimento da Criança, USP Rib. Preto, Paidéia, FFCLRP, 2000. Disponível em:

Distribuição das línguas, por Província http://paginaglobal.blogspot.com.br/2012/07/mocambique-o-pais-que-esta-conquistaro.html. 201215 de Março de 2013.

Distribuição geográfica de Moçambique. http://www.un.org/Depts/Cartographic/map/profile/mozambiq.pdf, Acesso: dia

Distribuição geográfica em línguas disponível: em; $<$ http://paginaglobal.blogspot.com.br/2012/07/mocambique-o-pais-que-estaconquistar-o.html. 2012>

FREUD, S. Totem e Tabú, Imago edição, Rio de Janeiro. 1999. 
GEERTZ, C. A Interpretação das Culturas, Livros Técnicos e Científicos, Editora S.A Rio de Janeiro, 1989.

GERALDO, A. F. \& MESSA A. A. Pais, filhos e deficiência: estudo sobre as relações familiares, Psic. Cienc. Prof. Vol. 27 P.236-245, 2007.

GLAT, R. O papel da família na integração do portador de deficiência, Belo Horizonte, $1995 . \quad$ Disponível em: $\leq$ http://educa.fcc.org.br/pdf/rbee/v02n04/v02n04a10.pdf $\geq$ Acesso: 27 de Mar.2013.

GOITEIN, P. C. \& CIA, F. Interações familiares de crianças com necessidades educacionais especiais: revisão da literatura nacional Revista Semestral da Associação Brasileira de Psicologia Escolar e Educacional,São Paulo,Vol.15, P. 43-51, Janeiro/junho, 2011.

Informação sobre o distrito de Sanga,disponível em: <http://www.portaldogoverno.gov.mz/Informacao/distritos/niassa/Sanga.pdf $>$ Acesso em 17 de Marc, 2013.

LEITE, D. M. Psicologia diferencial, São Paulo, editora S.A. 1966.

LEMES, L. C.\& BARBOSA M.A.M, Comunicando a mãe o nascimento do filho com deficiência, São Paulo, Out.Dez, Vol. 20, 2007

Mapa de Moçambique disponível em: http://www.un.org/Depts/Cartographic/map/profile/mozambiq.pdf, Acesso: dia 15 de Marc. de 2013

MILBRATH,V.M. et al. Comunicação entre a equipe de saúde e a família da criança com asfixia perinatal grave, Texto Contexto Enferm, Florianopolis, Out/Dez,2011.

MOÇAMBIQUE. Constituição da Republica de Moçambique. 2004. <http://www.law.yale.edu/rcw/rcw/jurisdictions/afe/mozambique/Mozambique_co nstitution.htm> Acesso: 20 de Set. 2012

Moçambique: $\mathrm{O}$ País que está a conquistar o mundo: disponível em: Shttp://paginaglobal.blogspot.com.br/2012/07/mocambique-o-pais-que-estaconquistar-o.html $\geq$ Acesso em: 21 Set. 2012.

MORALES, A. S. \& BATISTA, C. G. Compreensão da sexualidade por jovens com diagnóstico de deficiência intelectual, Psic.Teor. e Pesq, Vol. 26, P. 235-244, 2010. 
MOURA, L. \& VALÉRIO N. A família da criança deficiente, Cadernos de Pósgraduação em distúrbios do desenvolvimento, São Paulo, Vol.3 nr.1, P.47-51 2003.

MYNAYO, M. C. S. O Desafio do conhecimento: pesquisa qualitativa em saúde, editora: Hucitec, 2006.

PATTO, M. H. S. at. al. Formação de psicólogos e relações de professores: sobre a miséria da psicologia, São Paulo: Casa do Psicólogo, 2012.

PINHEIRO,S. N. S. Sexualidade e deficiência mental: revisando pesquisas, Psic. Educ. (impr),Vol. 8, nr. 2, P. 199- 206, 2004.

QUEIROZ, D. T. at. al. Observação Participante na pesquisa Qualitativa: conceitos e aplicação na área da saúde pública, R Enferm UERJ, Rio de Janeiro, Vol.2 P.276283, 2007.

REIS,..J. R. T. Família, emoção e ideologia:... In LANE,S. T. M. \& CODO, Wanderley.: editora brasiliense, 2011, P.99-123.

Rituais familiares: alternativas para a re-união as famílias disponível em: Seditorarevistas.mackenzie.br > ... > v. 4, n. 2 (2002) >Acesso: 7 de Mar.2013.

SILVA . N. L. \& DISSEN, M. A. O que significa ter uma criança com deficiência mental na família? Educar, Curitiba, nr: 23, P.161-183, 2004.

SOARES, A. H. R. et. AL. Jovens Portadores de deficiência : sexualidade e estigma, Ciênc. Saúde coletiva, Vol.13, nr.1 P. 185- 194, 2008.

SUAD, N. S. Preparando o caminho da inclusão- dissolvendo mitos e preconceitos em relação à pessoa com síndrome de down, 1. Ed- São Paulo: 2003.

WEGHER, I. M. C. Um olhar sobre Niassa, Paulinas editora- Maputo $1^{\text {o }}$ Volume1995.

Um olhares sobre Niassa, Paulinas editora -Maputo 2º volume- 1997. 


\section{ANEXO}

\section{Entrevistas}

\section{LÍDER TRADICIONAL :}

Régulo

\section{Quem são os Yaos?}

Os Yao começou com o regulo Mataka. O nome Yao vem do monte Yao. O regulo Mataka, e quem fazia troca pessoas de um lado para outro.

Conta-me um pouco sobre essa história dos Yaos?

Jaua, que e com e denominado as pessoas da etnia Yao, que nasceu no monte Yao. A história deste povo vem da divisão dos povos macuas e Nyanjas.

O que significa nascimento de uma criança neste povo?

O nascimento de uma criança nos Yaos e uma alegria, o jovem e ensinado a respeitar os mais velhos. Portanto o nascimento de uma criança e comemorado com alegria é motivo de festa.

Eu sei que os ritos de iniciação para esta comunidade e uma das praticas importantes! Existe uma diferença entre uma criança que tenha passado dos ritos e a outra não?

Sim existe uma grande diferença! Criança que passa pelos ritos de iniciação e, mas respeitosa, tem um tratamento de pessoas adultas. Os que não passam são mal educadas não respeitam os aos mais velhos e nem os hábitos da cultura.

\section{O que significa nascer uma criança com deficiência nesta comunidade?}

Quando nasce uma criança com deficiência, não e comemorado com festas, faz- se uma promessa (naciri),na perspectiva de ver ela curada, quando isso não acontece, não tem festa porque tem tristeza.

A criança com deficiência, passa dos ritos de iniciação quando atinge a idade? A educação e desde a infância entra-se no nyago (ritos de iniciação) a partir dos 12 anos. Uma criança deficiente pode não ser educada como outras crianças dependendo do tipo de deficiência. Pode ser submetida aos ritos da mesma forma que as outras crianças , só que existem certas coisas que crianças com deficiência não conseguem fazer. 


\section{PARTEIRA:}

Perguntei estaria disposta em participar da pesquisa, depois de falar do objetivo de trabalho.

\section{Ela respondeu:}

Ela disse que no primeiro momento estava com medo, porque esta existindo uma campanha contra agentes de saúde que roubavam equipamentos, nos hospitais, mas estou a vontade por saber que e apenas isso. Pode fazer as perguntas.

Assim comecei

\section{Como se chama?}

Odete

Há quantos anos trabalha como parteira?

Há 12 anos.

\section{Como e trabalhar como parteira neste centro?}

O trabalho e bom porque gosto do que faço, sempre que assisto um parto com sucesso e motivo de alegria.

\section{Quantos partos tem assistido semanalmente?}

Semanalmente, tenho assistido no mínimo 8 partos.

\section{Já alguma vez assistiu algum parto, complicado?}

Já isso não falta nessa nossa área, às parturientes são diferentes uma das outras.

Qual foi a reação da família diante da complicação?

Agente acaba conseguindo. Nem sempre e possível salvar a mãe e o bebe juntos, às vezes uma das pessoas não consegue resistir infelizmente.

Já aconteceu alguma vez diante da complicação, a família recorrer ao curandeiro ou adivinha?

Já nem sempre, mas acontece.

Qual tem sido a vossa reação como agentes de saúde quando isso acontece? 
Quando assim acontece nos não impedimos, porque reconhecemos a importância que os curandeiros têm para algumas famílias e principalmente na comunidade.

\section{Já assistiu algum parto em que a criança teria nascido deficiente?}

Já sim, nos serviços de maternidade tudo acontece.

\section{Qual tem sido a reação da família frente a isso?}

A reação dos pais e sempre de tristeza, desanimo, já tivemos caso em que a família acabou abandonando o filho, por considerar uma aberração.

\section{Qual tem sido a reação do pai nesse caso?}

Em muitos casos a reação dos pais e sempre de negar ate ao ultimo momento.

Que atitudes vocês tem tomado frente a essa atitude dos pais?

Tentamos sensibilizar, mas nem sempre funciona, porque se o parto for normal a mãe fica somente 24 no hospital e vai para casa, o que acontece depois não temos dito conhecimento.

\section{Já teve algum caso que mais lhe marcou durante esses anos todos de trabalho?}

Já esse caso eu nunca consegui esquecer ate hoje! De uma mulher que teve seu primeiro filho, com deficiência que eu nunca tinha visto na minha vida, em que o aspecto físico dele era completamente desfigurado a partir da boca, olhos, braços e pernas.

\section{Qual foi a atitude da mãe?}

A mãe aceitou a criança, mas não tinha vontade de amamentar, foi muito difícil ver aquela cena. Foram ao curandeiro, e constataram que foi a sogra que fez aquilo, porque estava descontente porque o filho casou-se com aquela mulher.

\section{O nascimento de crianças com deficiência é frequente?}

Tem nascido crianças com diferentes tipos deficiência, felizmente nem sempre isso acontece. 


\section{E tem deficiências que vocês dão prioridades no atendimento ate mesmo apoio?}

Todas as deficiências são prioritárias, mas dependendo da condição financeira de cada família, priorizamos as que tem menos recursos, principalmente no apoio alimentício.

Já existiram casos em que a família abandonou uma criança?

Já! Apesar de que não e muito frequente.

Que providencias vocês tomam quando isso acontece?

Nos apoiamos nos cuidados básicos que uma criança precisa mas contamos com ajuda do governo e principalmente com os serviços da ação social e casas de caridades, são os nossos melhores parceiros. 


\section{CURANDEIRO:}

Obrigado, por saber que o nosso trabalho e importante, infelizmente nem todas pessoas acham isso. Eu estou disposto em falar tudo que a mama quer saber.

\section{Como se chama?}

Tenho 69 anos.

\section{Seu nome completo?}

Esse e meu nome de trabalho, e nome que todas pessoas conhecem.

\section{A quantos anos faz esse trabalho?}

\section{A 37 anos.}

\section{Qual e seu trabalho principal?}

Curandeiro e adivinha, porque para eu começar a tratar, preciso, adivinhar o que a pessoa tem, por isso que esses dois trabalhos andam juntos.

Como e que tornou curandeiro?

Comecei com sentimentos de feitiço na família, dormia nas noites e acordava com crianças no mato. Andei km de distancia a procura de curandeiro. Cheguei ate a Malawi (Pais africano vizinho), onde encontrei um curandeiro que me recebeu com muito carinho.

Em principio fiquei como ajudante aprendiz e servente deste curandeiro durante um ano. Quando ele percebeu que eu estava preparado para trabalhar como curandeiro, despedi-me com o intuito de voltar para casa, o curandeiro não deixou ir, e ainda multou-me com valor muito alto. Como eu não tina dinheiro para pagar, passei a ser escravo do curandeiro, como forma de pagar a divida. Fui escravo do curandeiro durante um ano.

\section{Quando é que fez o seu primeiro trabalho como curandeiro?}

Quando consegui pagar a divida segui o meu caminho. O primeiro caso que eu atendi foi em Maputo capital de Moçambique.

\section{Qual e o segredo para o sucesso do seu trabalho?}

O segredo do curandeiro e ter machamba (rossa) para não ter que depender dos doentes, não pode ser oportunista. 


\section{Alguma vez já foi convidado a assistir algum parto complicado?}

Já fui convidado a acompanhar um parto, que tinha ver com coisas feitas por um tio e a criança nasceu com defeito na perna. Assisti esse doente junto aos médicos.

\section{O que tem feito quando os partos são difíceis?}

Se não for ir para lá pessoalmente, entrego o medicamento para família levar para onde esta essa mãe assim que ela tomar o parto acontece.

\section{Tem alguma amostra desse medicamento?}

Não, porque eu vou buscar no mato quando, aparecem as pessoas que precisam.

\section{Como era feito esse trabalho junto do medico?}

O doente estava de baixa (internado), e a família vinha aqui em casa me buscar ao hospital, ai eu dava raízes para tomar banho.

E esse doente curou?

Todos os casos que eu já tratei teve solução. Para ter solução nos casos que eu atendo faço manobra para conseguir.

\section{Que manobras?}

Isso e segredo do meu trabalho. Porque essas doenças tem sempre haver com questões familiares assim como de deus também.

E família faz algum ritual quando o filho esta sendo tratado?

O tratamento inclui a criança e mãe apenas.

Se der o caso dessa criança não curar, a quem e atribuída à culpa?

Colocam como culpado a pessoa que fez, por isso que antes eu preciso adivinhar.

Terminei a entrevista e agradeci pela colaboração dele.

\section{Curandeiro}

Se precisar de alguma coisa estou aqui. 


\section{AÇÃO SOCIAL:}

Responsável pela área da deficiência e apoio aos idosos.

Entrei em contacto com a direção Provincial de Ação social de Lichinga, através da secretaria, me apresentei falando do meu trabalho, e me indicaram Sendo encaminharam-me a ele, e foi super-receptivo e prometeu colaborar, ai comecei a colocar as questões.

\section{Começando por perguntar qual era o trabalho dele, como responsável da área?}

O meu trabalho como responsável desta área e garantir, que as pessoas que fazem parte deste programa sejam, contempladas aos nossos serviços recebam o apoio, necessário, de acordo as nossas possibilidades.

\section{Como assim de acordo com as nossas possibilidades?}

E que nem sempre nos conseguimos dar o apoio que cada um necessita, porque as nossas condições financeiras não permitem, ai nos vamos por prioridades.

\section{Como e que os casos chegam aos vossos serviços?}

Os casos chegam a nos, a partir das reportagens da própria comunidade, muitas das vezes.

Quais são as deficiências mais comuns que chegam aos vossos serviços?

Deficiência física, auditiva e visual.

\section{E deficiência mental?}

Deficiência mental existe, mas não são frequentes.

Quais são os casos que vocês dão prioridades?

Os casos que nos consideramos vulneráveis.

\section{E como são apurados esses casos vulneráveis?}

Levantamos um histórico social, a partir de uma visita domiciliaria. E apoio é feito de acordo com as suas necessidades. Por exemplo: se for um deficiente físico que tenha dificuldade de se locomover então a sua necessidade principal e de uma carinha roda.

Tem algum outro órgão que da assistência aos casos que vocês não podem atender por falta de condições financeiras.

Sim! São encaminhados ao INAS (instituto Nacional de Ação Social). 


\section{Qual e a diferença entre esses dois serviços?}

O INAS (Instituto Nacional de Ação Social) tem, mas recursos que a Ação social, nos prestamos pequenos apoios, enquanto que INAS vai para alem disso. Portanto só encaminhamos os casos ao INAS quando não conseguimos responder as necessidades dos casos que nos chegam. Que tipo de apoio vocês dão?

Portanto eles se beneficiam de um subsídio básico mensal de 130 meticais equivalente a 15 reais, este valor vai aumentando de acordo ao número do agregado familiar da pessoa deficiente. O que significa se a pessoa deficiente vive com uma pessoa, o apoio será de 260 e não d 130.

\section{E as pessoas continuam morando no seio familiar?}

Sim porque não temos condições de acomodar as pessoas, mas contanto com sempre com uma assistência comunitária. Que consiste em semanalmente ir um assistente social na casa dos beneficiários e observar como eles estão sendo tratados no seio familiar.

\section{Já alguma vez encontraram casos em que a família tratava mal?}

Já em que a família não queria saber do seu parente deficiente sob alegação de que é azar.

\section{Quando assim acontece o que vocês fazem?}

Quando assim acontece a é feito um trabalho de consciencialização pela ação social, no sentido de fazer entender a família que este individuo precisa deles.

\section{Existem outros serviços que vocês oferecem fora esses mencionados?}

Sim, temos centro de recursos de educação inclusiva, que está especificamente preparado para pessoas com deficiência auditiva, visual e física. 


\section{FAMÍLIA}

\section{Quantos fazem parte deste agregado familiar?}

Somos 10 pessoas.

\section{Quantos anos tem o Bernardo?}

15 anos de idade ele e o segundo filho.

Acha que o Bernardo e diferente dos outros irmãos?

Sim porque ele esta doente, não fala, e esta maluco.

\section{Como você percebeu que ele tinha problemas de saúde?}

Quando ainda era pequeno ele chorava muito fora do normal, gritava muito, eu o levei varias vezes ao hospital e sempre diziam que não tinha nada, quando eu levei ao curandeiro, ele disse que essa criança estava possuída pelo o espírito do irmão gêmeo falecido., Começamos a fazer tratamento tradicional e nunca deu efeito.

Como se sentiram quando o curandeiro, disse que ele estava possuído pelo espírito do irmão?

Fiquei triste porque eu perdi o outro meu filho, e o outro ficou maluco, são coisas de azar.

\section{O Bernardo Faz todas as atividades que os irmãos fazem? Se não. Porque?}

Ele não faz nada aqui em casa, apenas fica amarrado sempre, porque se deixar ele desamarrado, ele faz estragos não só aqui em casa, mas também em casa dos vizinhos senão vai lhe matar.

$3^{\circ}$ dia

Perguntei como eles tinham passado?

A avo respondeu: Contei com ajuda da vizinha Alice para interpretar o que a família ia trazendo. 
Estamos bem graças a deus. E devolveu-me a pergunta como esta mama ? eu respondi que estava bem também graças deus. E continuei perguntando e dessa vez a mãe foi respondendo.

\section{O Bernardo passou bem?}

Sim ele passou bem assim mesmo, mas gritou muito ontem.

\section{Mas porque será que ele grita tanta desse jeito?}

Não sei, eu acho que ele costuma ver alguma coisa mas como não fala fica complicado dizer o que e.

Nos dias que ele grita, consegue se alimentar normalmente?

Ele para de gritar, come e quando acaba d comer volta a gritar, e um grito que ate perturba os vizinhos, eu já não sei o que fazer.

\section{O que acontece para ele parar de gritar?}

Não acontece nada ele apenas para de gritar sozinho e fica muito quieto.

Eu sei que os rapazes na idade do Bernardo passam pelo Nyago,( ritos de iniciação ) será que o Bernardo passou?

Nada não passou.

\section{Porque?}

Porque senão ele pode ficar a mexer na ferida, e criar problemas sérios, ate pode vir a morrer, quando ele tem feridas em qualquer parte do corpo, ele vai tirando a casca da ferida e vai comendo. E também pode não ouvir os ensinamentos.

\section{Já tentou colocar o Bernardo na escola?}

Não.

\section{Porque?}

Porque tem esse problema desde criança, não fala, assim, não vai conseguir estudar. 


\section{O que Bernardo faz assim que amanhece ou durante o dia ?}

Ele não faz nada, não toma banho nem nada, ele só fica ai acorrentando, ate anoitecer, levamos comida para ele comer.

E quando anoitece ele dormi acorrentado também ?

Não! eu tiro ele da corrente e dormi com a avo, a minha mãe.

Que expectativas tem em relação ao Bernardo quando ele crescer?

Nenhuma! Ele não pode fazer nada, porque causa dessa doença dele.

\section{Como e que a comunidade se relaciona com o seu filho?}

Os vizinhos gostam dele, mas quando ele esta sossegado, quando não entra nas casas deles e fazer estragos, levar coisas deles, ate costumam vir aqui no quintal e chamar pelo nome dele Bernardo, Bernardo, Bernardo...

\section{E qual tem sido a reação dele quando o chamam?}

Ele só olha muitas das vezes, e outros dias quando esta bem disposto ri com eles.

\section{O que lhe faz ficar bem disposto?}

Depende dos dias, quando o espírito não lhe pega nesse dia ele fica disposto.

Parei de fazer perguntas fiquei sentada observando, e eles ficam todos olhando para mim, por vezes eu ate ficava sem graça. Me despedi na promessa de voltar na terça feira dia 27 de Novembro.

$4^{\circ}$ dia

Perguntei a mãe se ele nunca despertou interesse pela escola, mesmo vendo os irmãos indo a escola?

Não! Desde pequeno nunca mostrou essa vontade.

.A mãe do Bernardo disse que voltariam a machamba no sábado dia 30 e ficariam lá de vez. 
Gostaria de pedir para que eles ficassem mas tempo, infelizmente não devia fazer isso porque eles vivem daquele trabalho e já estava na época de sementeira. Então me despedi na promessa de voltar no dia 29 sexta feira que seria ultimo encontro.

\section{Ultimo visita}

Nesse momento ele sentou-se no banco que estava do meu lado. Avo pediu para que ele se retirasse daquele lugar ele não quis de jeito nenhum.

Ai eu perguntei a avo porque e queria que ele saísse de onde ele estava sentado?

Ela respondeu: ele esta muito sujo, não toma banho.

Mamã disse que ele fica acorrentado sempre, mas eu nunca encontrei ele acorrentado. Porque?

Quando mama vem aqui eu deixo ele assim sem por corrente.

\section{O que o Bernardo faz quando esta na machamba?}

Não faz nada, apenas fica andando de um lado para outro, as vezes foge para Sanga, mas volta sozinho.

Ele fica acorrentado na machamba?

Não.

\section{Porque?}

Lá não temos vizinhos, não tem como estragar nada de ninguém.

\section{Continuaram tentando outros tratamentos para a cura do Bernardo?}

Não! Depois daquela última vez que ele fugiu eu não tentei mas nenhum tratamento e nunca mais vou tentar, vou deixar assim mesmo.

\section{Porque?}

Eu acho que isso não tem cura, e ele não gosta de ouvir que será tratado, fica muito agitado.

E na machamba já tentaram algum tratamento? 
Não nunca tentei.

\section{E onde esta o pai do Bernardo?}

O pai, foi embora para Tanzânia, quando ele tinha dois anos nunca mais voltou.

\section{Teve uma pausa para o almoço:}

Onde eu fiquei observando.

Na hora da refeição mas uma vez, todos comiam no mesmo prato menos o Bernardo.

\section{Depois da refeição eu perguntei:}

Será que o Bernardo, por não ter passado dos ritos de iniciação, não visto mal por outros meninos da sua idade?

Não eles, nem ligam, porque sabem do estado dele.

Agradeci pela colaboração deles, me despedi com uma foto, e prometi voltar sempre que puder. 